\title{
Advances in mercury(II)-salt-mediated cyclization reactions of unsaturated bonds
}

\author{
Sumana Mandal, Raju D. Chaudhari and Goutam Biswas
}

\author{
Review \\ Address: \\ Department of Chemistry, Cooch Behar Panchanan Barma University, \\ Panchanan Nagar, Vivekananda Street, Cooch Behar - 736101, West \\ Bengal, India \\ Email: \\ Goutam Biswas* - goutam@cbpbu.ac.in \\ * Corresponding author \\ Keywords: \\ carbocyclic; catalyzed; cyclization; heterocyclic; mercury(II) salts
}

\author{
Beilstein J. Org. Chem. 2021, 17, 2348-2376. \\ https://doi.org/10.3762/bjoc.17.153 \\ Received: 24 May 2021 \\ Accepted: 27 August 2021 \\ Published: 09 September 2021 \\ Associate Editor: L. Ackermann \\ (C) 2021 Mandal et al.; licensee Beilstein-Institut. \\ License and terms: see end of document.
}

\begin{abstract}
The synthesis of complex cyclic compounds is extremely challenging for organic chemists. Many transition-metal-salt-mediated cyclizations are reported in literature. $\mathrm{Hg}$ (II) salts have been successfully employed in cyclizations to form complex heterocyclic and carbocyclic structures that are impossible to synthesize with other transition metal salts. In this review, we have summarized cyclization reactions that are performed with $\mathrm{Hg}$ (II) salts. These salts are also successfully applied in stoichiometric or catalytic amounts to form complex cyclic structures and natural products.
\end{abstract}

\section{Introduction}

The use of transition metal reagents has found considerable applications in organic synthesis [1-4] and has radically changed the realm of chemical science. It also provides a powerful tool for the construction of complex molecular frameworks [5-7]. A plethora of reviews involving transition metals such as $\mathrm{Pd}(\mathrm{II})$ [8-10], Ru(II) [11-13], Rh(III) [14-16], Mn(II) [17-19], Au(II/I) [20-22], $\mathrm{Ag}(\mathrm{I})$ [23-25] etc. in both cascade and sequential reactions have been published. Electrophilic $\mathrm{Hg}$ (II) salts are important reagents in organic synthesis and there is published literature establishing this fact [26-29]. However, the main drawback of $\mathrm{Hg}(\mathrm{II})$ salts, as compared to other transition metal salts, is their increased toxicity $[30,31] . \mathrm{Hg}(\mathrm{II})$ salts on the other hand, are very cheap in comparison to other transition metal salts (Table 1) and one of the soft Lewis acids of the periodic table [32]. $\mathrm{Hg}$ (II) salts have already manifested some unique reactivity and therefore attracted increasing interest from chemists [33]. Many examples involving $\mathrm{Hg}$ (II) salts with unsaturated bonds in presence of various nucleophiles giving rise to various types of products are abound in the literature. Utilization of $\mathrm{Hg}$ (II) salts in the intramolecular cationic cyclization of olefinic, acetylenic, and allenic substrates having aromatic rings, nucleophiles, and heteroatoms in the neighborhood were well documented. $\mathrm{Hg}$ (II) reagents were also often employed in the important cyclization step during total syntheses of many 
natural products [34]. Despite its wide application in ring formation reactions, only a few review articles on $\mathrm{Hg}$ (II)-saltmediated cyclization reactions are available in the literature [35]. This review describes the intramolecular cyclization of unsaturated compounds in the presence of stoichiometric/catalytic amounts of $\mathrm{Hg}$ (II) salts. The classification of this review is based on the following topics.

- Cyclization reactions involving the stoichiometric amount of $\mathrm{Hg}(\mathrm{II})$ salts.

- Cyclization reactions involving the catalytic amount of $\mathrm{Hg}(\mathrm{II})$ salts.

- Total synthesis involving $\mathrm{Hg}(\mathrm{II})$-salt-mediated cyclization reactions.

Table 1: Comparison of price of reagent grade $\mathrm{Hg}$ (II) salts with other transition metal salts.

\begin{tabular}{|c|c|c|}
\hline Name of salts & CAS No. & Price $\$ / g^{a}$ \\
\hline mercury(II) chloride $\mathrm{HgCl}_{2}$ & $7487-94-7$ & $0.67^{\mathrm{b}}$ \\
\hline mercury(II) acetate $\mathrm{Hg}(\mathrm{OAc})_{2}$ & $1600-27-7$ & $1.35^{\mathrm{b}}$ \\
\hline mercuric triflate $\mathrm{Hg}(\mathrm{OTf})_{2}$ & $49540-00-3$ & $12.7^{c}$ \\
\hline mercury(II) perchlorate $\mathrm{Hg}\left(\mathrm{ClO}_{4}\right)_{2}$ & $304656-34-6$ & $2.83^{\mathrm{C}}$ \\
\hline auric chloride $\mathrm{AuCl}_{3}$ & $13453-07-1$ & $112^{\mathrm{d}}$ \\
\hline silver perchlorate $\mathrm{AgClO}_{4}$ & $7783-93-9$ & $8.24^{\mathrm{C}}$ \\
\hline platinum chloride $\mathrm{PtCl}_{2}$ & $10025-65-7$ & $115^{\mathrm{d}}$ \\
\hline
\end{tabular}

aprices are from http://www.sigmaaldrich.com (as on 05-08-2021). ${ }^{b} 100 \mathrm{~g},{ }^{c} 25 \mathrm{~g},{ }^{d} 5 \mathrm{~g}$ pack size.

The generalized mechanism for cyclization reactions are, alkenes/alkynes 1 initially react with $\mathrm{Hg}(\mathrm{II})$ salts $\left(\mathrm{HgX}_{2}\right)$ leading to the formation of a mercurial carbonium ion $\mathbf{2}$ followed by the attack of an intramolecular nucleophile giving rise to a cyclized mercuro-halide complex compound $\mathbf{3}$ (Scheme 1).

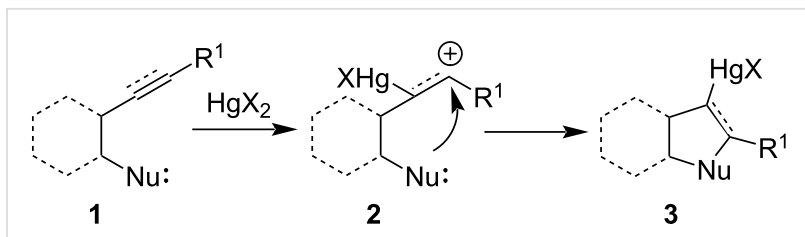

Scheme 1: Schematic representation of $\mathrm{Hg}(\mathrm{II})$-mediated addition to an unsaturated bond.

\section{Review}

\section{Cyclization reactions involving stoichiometric} amounts of $\mathrm{Hg}$ (II) salts Cyclization involving alkenes $(>\mathrm{C}=\mathrm{C}<$ )

In 1900 and 1901, the Sand and Biilmann group had first reported the $\mathrm{Hg}$ (II)-mediated cyclization of allyl alcohol using $\mathrm{Hg}(\mathrm{II})$ nitrate $\left(\mathrm{Hg}\left(\mathrm{NO}_{3}\right)_{2}\right)$ in two separate publications [36,37]. The cyclized product thus formed was further treated with iodine to get trans-2,5-bis(iodomethyl)-p-dioxane (4a). The formation of trans-isomer $\mathbf{4 a}$ as the major product and cis-isomer 4b as a minor product was later confirmed by Summerbell et al. by repeating the same experiments (Scheme 2) [38].

Cyclization of biallyl ether $\mathbf{5}$ in presence of mercuric acetate $\left(\mathrm{Hg}(\mathrm{OAc})_{2}\right)$ in an aqueous medium was reported to synthesize a diastereomeric mixture of 2,6-disubstituted-p-dioxane $\mathbf{6}$. The outcome of the reaction was much generalized with no detailed discussion about the ratio of diastereomeric products [39]. Later, Summerbell and co-workers modified the reaction conditions to synthesize 2,6-disubstituted dioxane derivatives 6 (cis/trans 16:1). Unlike 2,5-disubstituted dioxane derivatives, here the $c i s$-isomer was the major product. A higher ratio of the cis-dioxane $\mathbf{6}$ was achieved by increasing the reaction time and acidity of the reaction medium, while elevated temperature showed no effect (Scheme 3) [40].

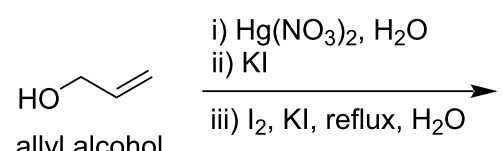

allyl alcoho iii) $\mathrm{I}_{2}, \mathrm{KI}$, reflux, $\mathrm{H}_{2} \mathrm{O}$<smiles>[CH]C1CO[C@@H](CI)CO1</smiles>

4a, $90 \%$<smiles>CC1COC(C)CO1</smiles>

4b

Scheme 2: First report of $\mathrm{Hg}$ (II)-mediated synthesis of 2,5-dioxane derivatives from allyl alcohol.

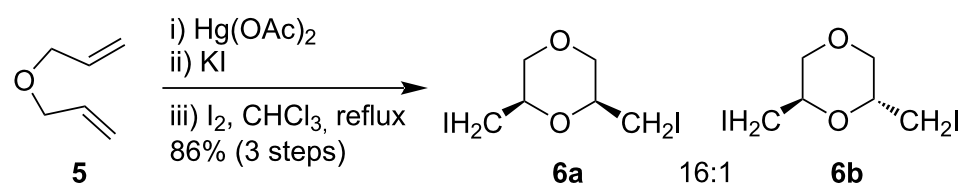

Scheme 3: Stepwise synthesis of 2,6-distubstituted dioxane derivatives. 
The mercuricyclization was also employed in the field of carbohydrate chemistry for the synthesis of $\alpha$-D- $C$-glycopyranosyl derivatives. The reaction between carbohydrate alkene precursor 7 and $\mathrm{Hg}(\mathrm{OAc})_{2}$ proceeds with high stereoselectivity to give the $\alpha$-D-C-glycopyranosyl derivative (1,5-trans-isomer) 8 as a single isomer [41]. Treatment of compound $\mathbf{8}$ with sodium borohydride $\left(\mathrm{NaBH}_{4}\right)$ under phase transfer conditions (PTC) yields compound 9 as the only product. The selectivity of $\alpha$-stereochemistry was primarily due to the strong directing effect of the neighboring benzyl ether group with the $\mathrm{Hg}(\mathrm{OAc})_{2}$. When cyclic mercuric halide 8 was treated with $\mathrm{NaBH}_{4}$ and oxygen $\left(\mathrm{O}_{2}\right)$ in DMF oxidative demercuration takes place to give alcohol $\mathbf{1 0}$ in quantitative yield (Scheme 4).

The methodology utilized in Scheme 5 had been successfully employed for the preparation of $C$-glycopyranosyl derivatives of common and uncommon sugars like $\alpha$-gluco, $\alpha$-manno, $\beta$-altro, $\beta$-ido, $\alpha$ - and $\beta$-gulo, $\beta$-talo, $\alpha$-galacto, and $\alpha$-allo $C$-glycopyranosides [42]. Vinylated derivatives of aldopentoses 11 were treated with $\mathrm{Hg}(\mathrm{OAc})_{2}$ affording the corresponding cyclized pyanosylmethylmercuric chloride derivatives $\mathbf{1 2}$ (Scheme 5). This methodology can be used to synthesize rare $C$-glycosyl carbohydrates from easily available sugars.

In a similar manner, stereoselective cyclization of $C$-glycosyl amino acid derivative $\mathbf{1 3}$ using mercuric trifluoroacetate $\mathrm{Hg}(\mathrm{TFA})_{2}$ at room temperature was performed. The reaction proceeds primarily through stereoselective cyclization to give $\alpha$-D- $C$-glycopyranosyl amino acid derivative $\mathbf{1 4}$ as the major product [43]. Nevertheless, $C$-mannopyranosyl derivatives cannot be achieved in a similar manner as reductive elimination forms during the mercury removal process (Scheme 6).

Mercury(II) salts had been effectively used to synthesize fivemembered furanose derivatives with high stereoselectivity. Nicotra et al. developed $\mathrm{Hg}(\mathrm{OAc})_{2}$-mediated cyclization of hydroxy-alkene derivative $\mathbf{1 5}$ to form $\alpha$-D-ribose derivative $\mathbf{1 6}$ at room temperature (Scheme 7). They had confirmed the formation of the $\alpha$-isomer of D- $C$-ribofuranosyl 16 predominantly over the $\beta$-isomer $(\alpha / \beta$ 95:5) [44].

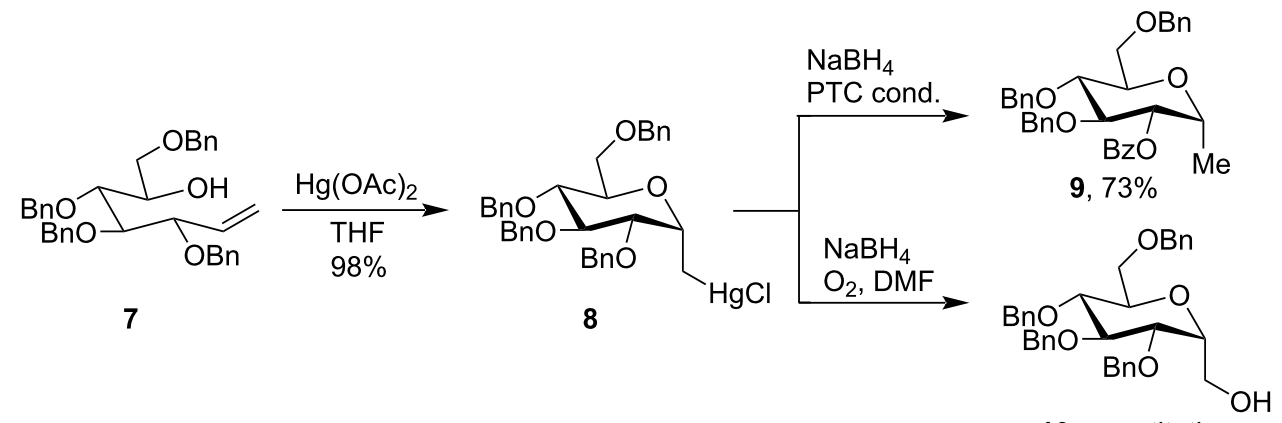

10, quantitative

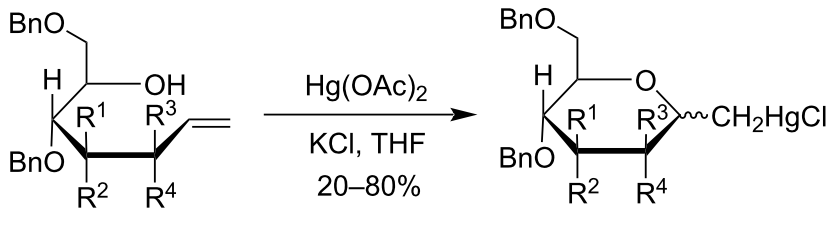

11

12
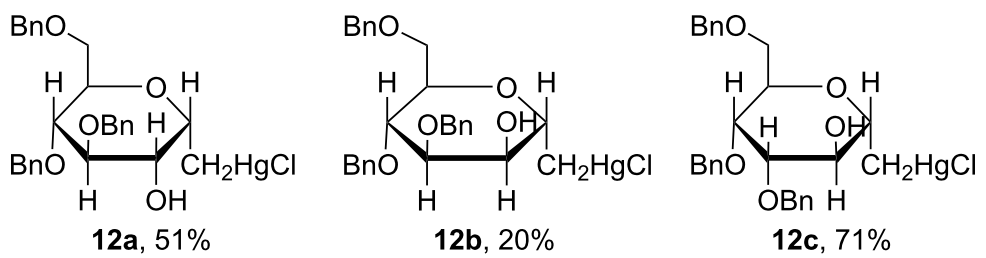

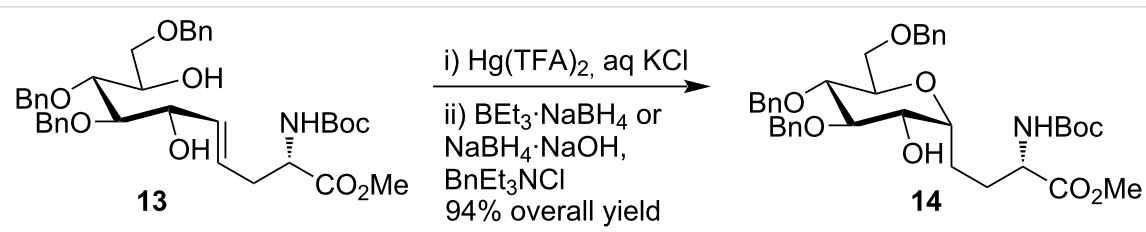

Scheme 6: Synthesis of $C$-glycosyl amino acid derivative using $\mathrm{Hg}(\mathrm{TFA})_{2}$.<smiles>C=C[C@H]1OC(C)(C)O[C@@H]1C(O)C[O-]</smiles>

15

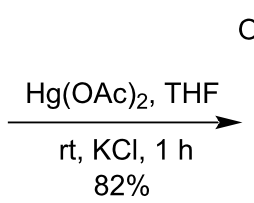

$82 \%$<smiles>CC1(C)OC2[C@@H](O1)C(C[O-])O[C@@H]2CCCl</smiles>

$16(\alpha / \beta 95: 5)$
Scheme 7: $\mathrm{Hg}(\mathrm{OAc})_{2}$-mediated synthesis of $\alpha$-D-ribose derivative.

In contrast, when Reitz and co-workers carried out a ring formation of benzylated $C$-arabinofuranoside derivative $\mathbf{1 7}$ in presence of 1.4 equiv of $\mathrm{Hg}(\mathrm{OAc})_{2}$ and sodium bromide $(\mathrm{NaBr})$ at room temperature, then $\beta$-D-arabinose derivative $\mathbf{1 8}$ was formed as the major product (Scheme 8) [45]. The high stereoselectivity of $\beta$-derivative $\mathbf{1 8}$ at the anomeric position was predominantly due to the presence of the benzyl groups at the C-2 and C-3 positions of the starting material.

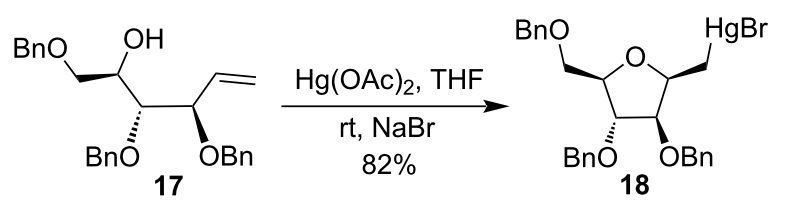

Scheme 8: Synthesis of $\beta$-D-arabinose derivative 18.

It had been cited in many publications that the stereoselectivity of products formed due to $\mathrm{Hg}$ (II)-salt-mediated cyclization reactions of alkene-alcohol derivatives depends on several factors: the nature of the $\mathrm{Hg}$ (II) salts [46], the starting materials
[47], and the effect of $\mathrm{H}_{2} \mathrm{O}$ (protic solvent) in the reaction media [48].

Pulido et al. had developed a conversion of allylsilyl alcohols 19 to diastereomeric mixtures of tetrahydrofuran derivatives 20A and 20B (Scheme 9) [47]. It was reported that more substituted alkyl groups present in allylsilyl alcohol 20b direct the selective formation of diastereomeric products. They also observed that changes in $\mathrm{Hg}(\mathrm{II})$ salts result in different ratios of the cis- and trans-isomer in the cyclized products [47]. The differences in cis and trans ratios were primarily due to the basicity of anions associated with $\mathrm{Hg}$ (II) salts [46].

A similar type of reaction methodology was employed for the formation of a bicyclic nucleoside analog. 4'- $C$-vinylribofuranoside derivative 21 on treatment with $\mathrm{Hg}(\mathrm{TFA})_{2}$ followed by reduction with $\mathrm{NaBH}_{4}$ leads to the formation of bicyclic nucleoside derivative 22 (Scheme 10) [49].

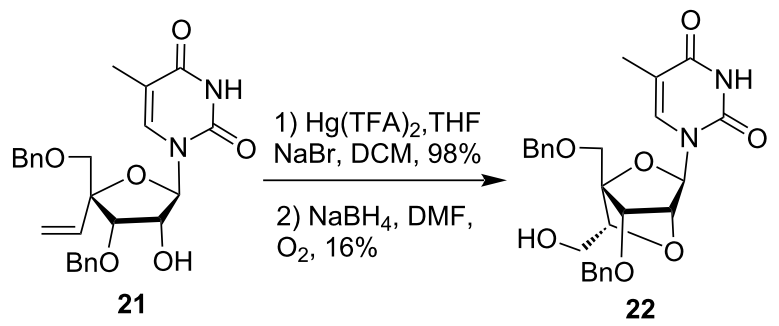

Scheme 10: Synthesis of $\mathrm{Hg}(\operatorname{TFA})_{2}$-mediated bicyclic nucleoside derivative.<smiles>[R]C(O)CC([R])([R])C(=C)CS(C)(=O)=O</smiles>

20a, 68\%, A/B 50:50

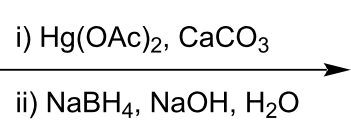

DMPS $=\mathrm{PhMe}_{2} \mathrm{Si}$ $\mathrm{R}^{1}, \mathrm{R}^{3}=\mathrm{H}$

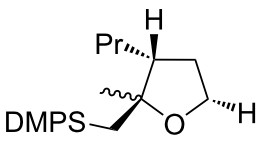

20b, $85 \%, A / B$ 66:34
DMPS<smiles>[R]C1CC([R])([R])C(CC)(CC)O1</smiles><smiles>[R]C1CC([R1])[C@](C)(CS(C)(=O)=O)O1</smiles>

DMPS<smiles>CC[C@@]1(c2ccccc2)OCC[C@H]1c1ccccc1</smiles><smiles>CC[C@H]1C[C@H](C)O[C@]1(C)CS(C)(=O)=O</smiles>

20c, $68 \%, A / B$ 50:50

20d, $70 \%, A / B$ 50:50 
Pyrrolidine and piperidine derivatives were also synthesized by $\mathrm{Hg}$ (II)-salt-induced cyclization. $N$-Isopropyl-1-aminohex-4-ene (23) on treatment with 1 equiv $\mathrm{HgCl}_{2}$ followed by reduction with $\mathrm{NaBH}_{4}$ yielded pyrrolidine $\mathbf{2 4}$ and piperidine derivative $\mathbf{2 5}$ in the ratio of 7:3 [50]. $N$-Methylaniline derivative 26 undergoes cyclization with $\mathrm{HgCl}_{2}$ and gave cis-mercuro chlorides 27 and $\mathbf{2 8}$ as isolated products (Scheme 11) [51].

For the synthesis of diastereomeric pyrrolidine derivatives, a $\mathrm{Hg}$ (II) salt had been used. When $\mathrm{HgCl}_{2}$ was added to secondary methylamine derivatives $\mathbf{2 9}$ and $\mathbf{3 1}$ followed by reduction with $\mathrm{NaBH}_{4}$ a mixture of diastereomers 30a,b and 32a,b was obtained, respectively. trans-Isomers were formed as major products over cis-isomers (Scheme 12) [52].

Five- and six-membered $N$-containing heterocyclic phosphonates were synthesized by intramolecular cyclization of alkenyl $\alpha$-aminophosphonates in a similar way with the treatment of $\mathrm{Hg}(\mathrm{OAc})_{2}$ [53]. The cyclized products 34A,B formed from starting material $\mathbf{3 3}$ were regiospecific and followed Markovnikoff's type addition in the reaction [54-57]. It was also reported that the formation of $\alpha$-phosphorylated pyrrolidines mostly takes place in regio- and stereoselective ways depending on the reaction conditions (Scheme 13) [53,58].<smiles>C/C=C\CCCNC(C)C</smiles>

23<smiles>C/C=C\Cc1ccccc1NC</smiles>

26

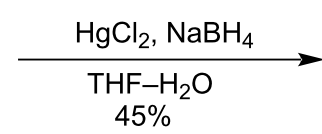

$45 \%$

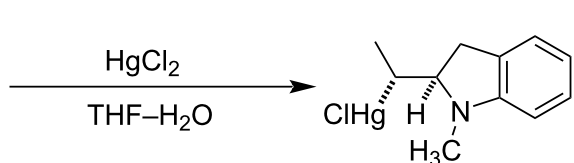

27<smiles>CC(C)N1CCCCC1C</smiles>

$7: 3$

25<smiles>C[C@H]1[C@H](Cl)Cc2ccccc2N1C</smiles>

28

Scheme 11: Synthesis of pyrrolidine and piperidine derivatives.

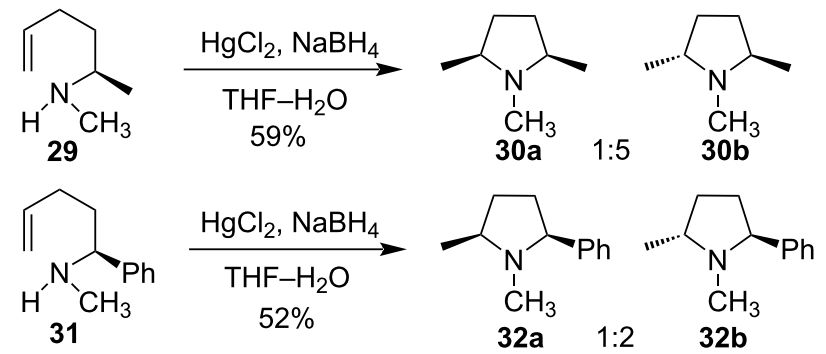

Scheme 12: $\mathrm{HgCl}_{2}$-mediated synthesis of diastereomeric pyrrolidine derivatives.<smiles>[R]C([R])=C([R])CCC(N)([Po])[R6]OCC</smiles>

33

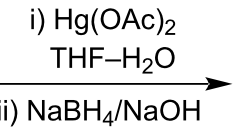

(37-81\%)<smiles>[R]C([R])C1([R])CCC(C)([PH2]OCC)N1</smiles>

34A<smiles>[R]C([R])[R]</smiles>

34B<smiles>CCOO[Pb]1(C)CCC(C)(C)N1</smiles>

$34 a, 72 \%$<smiles>CCO[Po+2](C)C1(C)CCC(C(C)C)N1</smiles>

34b, 37\%

cis/trans 28:72<smiles>CCOOC(C)(C)[C@H]1CC[C@@H](C)N1</smiles>

34c, $81 \%$

cis/trans 17:83 
Cyclization of 4-cycloocten-1-ol (35) with $\mathrm{Hg}(\mathrm{OAc})_{2}$ resulted in formation of two types of fused bicyclic products, 9-oxabicyclo[3.3.1]nonane (36) and 9-oxabicyclo[4.2.1]nonane (37) (Scheme 14) $[59,60]$. It was observed that the regioselective synthesis of 9-oxabicyclo[4.2.1]nonane (37) was favored when $\mathrm{NaBH}_{4}$ and sodium acetate $\mathrm{NaOAc}$ were present, while in absence of $\mathrm{NaOAc}$, 9-oxabicyclo[3.3.1]nonane (36) was formed as an exclusive product.

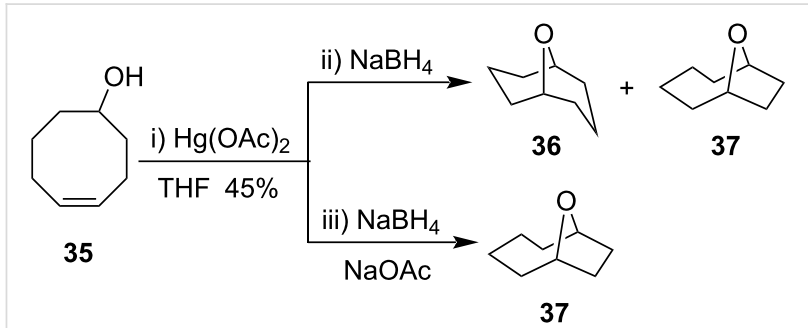

Scheme 14: Cyclization of 4-cycloocten-1-ol with $\mathrm{Hg}(\mathrm{OAc})_{2}$ forming fused bicyclic products.

In a similar manner, an aminomercuration reaction had been successfully employed in the cyclization of trans-amino alcohol 38 leading to the formation of $(1 R, 2 R, 6 R)$-9-benzyl-9-azabicyclo[4.2.1]nonan-2-ol (39). The bicyclic derivative 39 through the number of consequent reactions formed a highly potent $(+) /(-)$-pyrido[3,4-b]homotropane (40), a bridged nicotinoid (Scheme 15) [61].
Similarly, precursor $\mathbf{4 1}$ at room temperature in the presence of $\mathrm{Hg}(\mathrm{OAc})_{2}$ (1 equiv) in $\mathrm{CH}_{2} \mathrm{Cl}_{2}$ cyclized to form 2-aza- or 2-oxabicyclic mercuri derivatives. Further, treatment of intermediates with $\mathrm{NaBH}_{4}$ (4 equiv) in presence of $5 \%$ aq $\mathrm{NaOH}$ solution for 1 hour at room temperature produced bicyclic derivatives 42 (Scheme 16) [62]. The diasteroselectivity of the products formed depends on the heteroatoms involved; azamercuration yields more selectivity than oxymercuration.

Nixon et al. reported a $\mathrm{Hg}(\mathrm{II})$-salt-induced alkenyl hydroperoxide 43 cyclization to synthesize cyclic peroxides 44 as the major product, which on further treatment with $\mathrm{NaBH}_{4}$ gives compound 45 along with the unexpected product $\mathbf{4 6}$ (Scheme 17) [63].

Later they had reported the reaction between alkenyl hydroperoxide 47 and aldehydes 48 to form hemiperoxyacetal 49 which subsequently reacted with $\mathrm{Hg}(\mathrm{OAc})_{2}$ and a catalytic amount of perchloric acid $\left(\mathrm{HClO}_{4}\right)$ forming cyclized product 1,2,4-trioxanemercuri bromide 50. The product thus formed was reduced with $\mathrm{NaBH}_{4}$ to form compound 51 (Scheme 18) [64].

Kurbanov et al. first reported the cyclization of different isoprenoid derivatives to hexahydrochromene derivatives using $\mathrm{Hg}$ (II) salts [65]. They had shown that trans-geranylacetone (52) produces trans-2,5,5,9-tetramethylhexahydrochromene (53) while the cis-cyclized product was formed from cis-

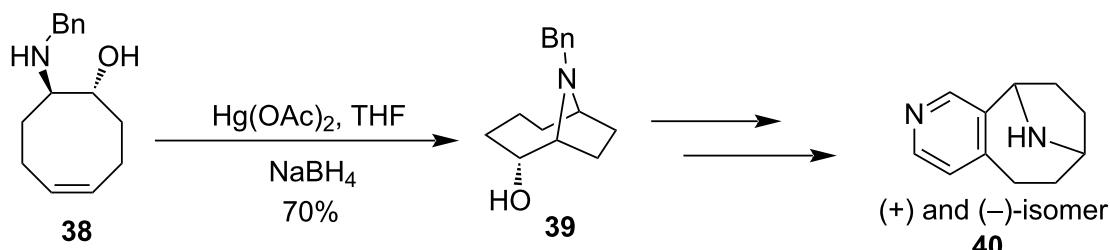

Scheme 15: trans-Amino alcohol formation through $\mathrm{Hg}(\mathrm{II})$-salt-mediated cyclization<smiles>[R]OC1(C/C=C\C)CCC[C@H]1[Y]</smiles>

erythro

41<smiles>COC(=O)[C@]12CCC[C@H]1N[C@H](C)C2</smiles>

42a, $64 \%$ endolexo 3:1

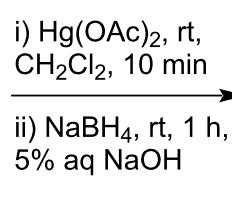<smiles>CCOC(=O)[C@]12CCC[C@H]1N[C@H](C)C2</smiles>

42b, $71 \%$ endolexo 19:1

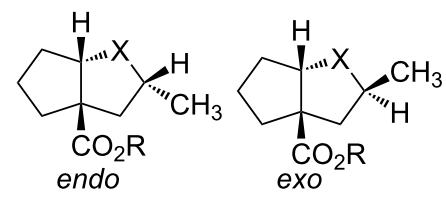

42<smiles>COC(=O)[C@]12CCC[C@H]1O[C@@H](C)C2</smiles>

42c, $58 \%$ endo/exo 1:1.6

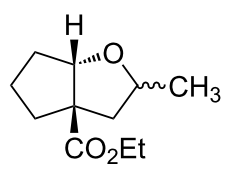

42d, $55 \%$

endo/exo 1:1.1 


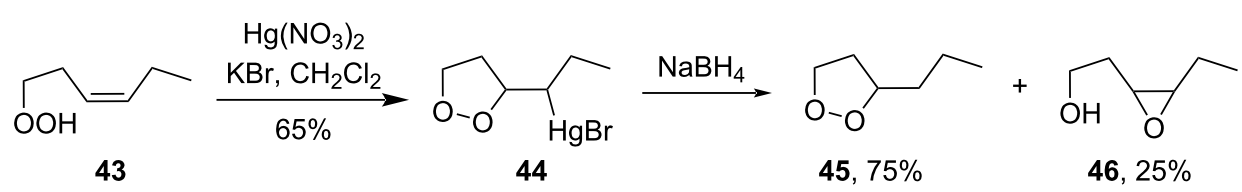

Scheme 17: $\mathrm{Hg}(\mathrm{II})$-salt-induced cyclic peroxide formation.

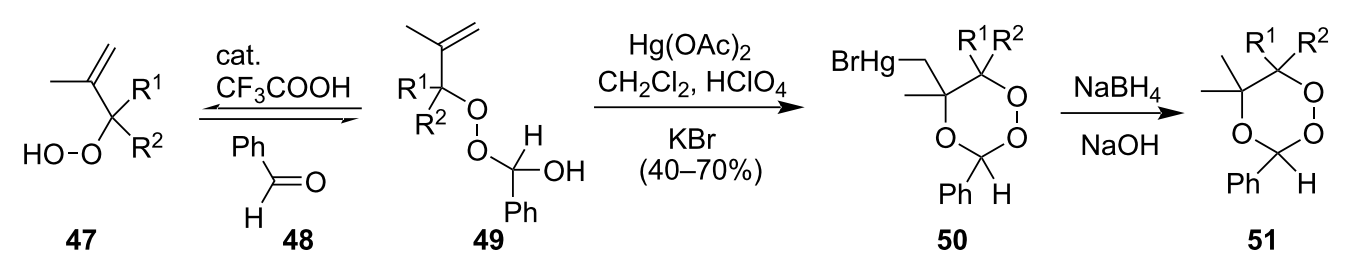

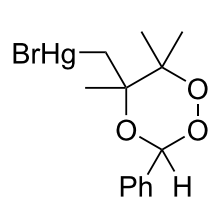

$50 a, 40 \%$<smiles>CC1OOC(c2ccccc2)(c2ccccc2)OC1(C)CCBr</smiles>

50b, dr $84 \%$<smiles>CC(C)C1OOC(c2ccccc2)(c2ccccc2)OC1(C)CCBr</smiles>

50c, $\mathrm{dr}>97 \%$<smiles>CCOCC1OOC(c2ccccc2)(c2ccccc2)OC1(C)CCBr</smiles>

50d, dr $>97 \%$

Scheme 18: $\mathrm{Hg}(\mathrm{OAc})_{2}$-mediated formation of 1,2,4-trioxanes.

isoprenoid derivatives. Later, Hoye et al. used similar reaction conditions to cyclize dienes 54 with 1.1 equiv of $\mathrm{Hg}(\mathrm{TFA})_{2}$ to yield endocyclic enol ether $\mathbf{5 5}$ in almost quantitative yield [66]. They had also performed experiments with different isoprenoid derivatives (carboxylic acid, ketones alcohols, and keto esters) to form different bicyclic products (Scheme 19).

A $\mathrm{Hg}(\mathrm{II})$-salt-promoted cyclization of amidal $\mathbf{5 6}$ was performed to synthesize optically active cyclic alanine derivatives 57 as 1:1 diastereomeric mixture [67]. Diastereomers were further separated by column chromatography and afforded enantiomerically pure isomers of $\mathrm{N}$-substituted imidazolidine-4ones 57 (Scheme 20).

In a similar manner, $\mathrm{N}$-Cbz-protected amine $\mathbf{5 8}$ undergoes cyclization using $\mathrm{Hg}(\mathrm{TFA})_{2}$ (1 equiv) and yielded a dinitrogencontaining mixture of diastereomeric alicyclic derivatives $\mathbf{5 9}$.<smiles>CC(=O)CC/C=C(/C)CCC=C(C)C</smiles>

52<smiles>COC(=O)C(CC=C(C)CCC=C(C)C)C(C)=O</smiles>

54

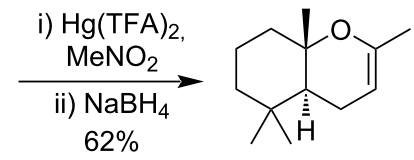

53
Scheme 19: Endocyclic enol ether derivative formation through $\mathrm{Hg}$ (II) salts.

The tetrahydropyrimidin-4(1H)-one-mercuri trifluoroacetate derivative $\mathbf{5 9}$ on successive treatment with $\mathrm{NaBr}$ and $\mathrm{LiBH}_{4}$ gives a mixture of tetrahydropyrimidin- $4(1 H)$-one derivatives $\mathbf{6 0}$ in<smiles>C=CC(=O)N(CNC(=O)OCc1ccccc1)C(C)c1ccccc1</smiles>

56 i) $\mathrm{Hg}(\mathrm{TFA})_{2}, 1.1$ equiv $\underset{\text { dry } \mathrm{CH}_{2} \mathrm{Cl}_{2}, 0^{\circ} \mathrm{C}, 20 \mathrm{~min}}{\longrightarrow}$

ii) $\mathrm{NaBH}_{4}$ (1.1 equiv) dry $\mathrm{CH}_{3} \mathrm{CN}, 0^{\circ} \mathrm{C}, 30 \mathrm{~min}$ quantitative yield<smiles>CC1C(=O)N(C(=O)OCc2ccccc2)CN1C(C)c1ccccc1</smiles> 
the diastereomeric ratio of 63:37 after separation by column chromatography [68] (Scheme 21).

Mercury(II) salts had also been successfully utilized in the cyclization of ether derivatives $\mathbf{6 1}$ to form stereoselectively trans-4,5-disubstituted oxazolidine derivatives 62 (Scheme 22) [69]. Later it was reported, when homologous allyloxycarbamate derivative 63 was cyclized with $\mathrm{Hg}(\mathrm{TFA})_{2}$ then five- and six-membered rings $\mathbf{6 4}$ and $\mathbf{6 5}$ were formed with a 1:4 ratio (Scheme 22) [70]. The greater yield of the six-membered prod- uct was primarily due to the electron-withdrawing effect of ethereal oxygen which in turn destabilizes the carbocation at the $\beta$-carbon and hence the nucleophilic attack at the $\gamma$-carbon took place.

Cyclization of amide derivative $\mathbf{6 6}$ induced by $\mathrm{Hg}(\mathrm{OAc})_{2}$ followed by reduction with $\mathrm{LiBH}_{4}$ afforded a mixture of compounds $67 \mathrm{~A} / 67 \mathrm{~B}$ [71]. The formation of endo,trans-product as a major product over the exo,cis-isomer was primarily due to a stereoinduction effect (Scheme 23). The small amount of

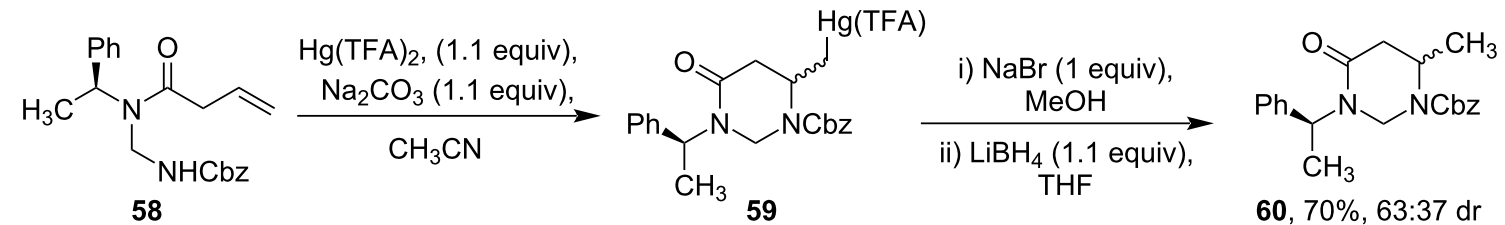

Scheme 21: $\mathrm{Hg}(\mathrm{II})$-salt-mediated formation of tetrahydropyrimidin-4(1H)-one derivatives.

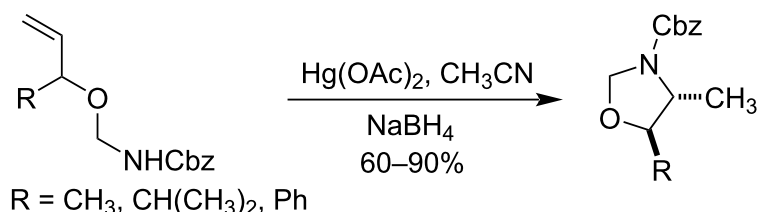

61

62<smiles>CC=CC(C)OCNC(C)=O</smiles>

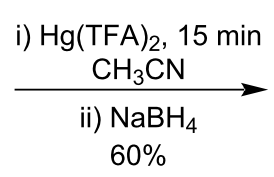

63<smiles>CCC1C(C)OCN1C(=O)OCc1ccccc1</smiles>

64

is/trans $1: 2$<smiles>CC1C[C@@H](C)N(C(=O)OCc2ccccc2)CO1</smiles>

$1: 4 \quad 65$

cis/trans 17:1

Scheme 22: Cyclization of ether derivatives to form stereoselective oxazolidine derivatives.<smiles>[R]C(C=C)O[C@@H]1NC(=O)c2ccccc21</smiles>

66 i) $\mathrm{Hg}(\mathrm{OAc})_{2}, 2.2$ equiv $\mathrm{NaHCO}_{3}$ $\mathrm{CH}_{3} \mathrm{CN}, 25^{\circ} \mathrm{C}, 10 \mathrm{~min}$

ii) $\mathrm{LiBH}_{4}, \mathrm{THF},-78^{\circ} \mathrm{C}$

(74-93\%)<smiles>[R]C1O[C@]2([2H])c3ccccc3C(=O)N2[C@H]1C</smiles>

67A<smiles>[R]C1O[C@]2([O-])c3ccccc3C(=O)N2C1C</smiles><smiles>C[C@@H]1O[C@@H]2c3ccccc3C(=O)N2[C@H]1C</smiles>

67a, $75 \%$

cis/trans 0.7:99.3<smiles>C[C@H]1C(CCc2ccccc2)O[C@@H]2c3ccccc3C(=O)N12</smiles>

67b, $93 \%$<smiles>C[C@@H]1C(Cc2ccccc2)O[C@H]2c3ccccc3C(=O)N21</smiles>

67c, $74 \%$ 
exo,cis-isomers $67 \mathrm{Ba} / 67 \mathrm{Bc}$ was only detected by HPLC analysis of the crude reaction mixture.

Takacs et al. observed the rapid cyclization of salicylamidederived amidal auxiliary derivatives $\mathbf{6 8}$ and $\mathbf{7 0}$ in presence of 1.5 equiv of a $1: 1$ mixture of $\mathrm{Hg}(\mathrm{OAc})_{2} / \mathrm{Hg}(\mathrm{TFA})_{2}$ resulting in a diastereomeric pair of cyclized products 69 and 71, respectively. It was observed that the cis-isomer was predominant in the case of the five-membered ring while the trans-isomer was predominant in the case of the six-membered ring formation (Scheme 24) [72].

\section{Cyclization involving alkynes $(-\mathrm{C} \equiv \mathrm{C}-)$}

$\mathrm{Hg}$ (II)-salt-mediated cyclizations were also observed in the case of alkynes. Arylalkynes $\mathbf{7 2}$ were cyclized via $\mathrm{Hg}$ (II)-salt-in- duced reactions to form benzopyran derivatives 73 [73-75]. Interestingly in the case of 1-aryloxy-4-arylthio-2-butyne derivatives $\mathbf{7 4}$, selective ring closure on the oxygen side afforded 6-membered chromene derivatives $\mathbf{7 5}$ but no thiochromene derivatives were observed [76]. Compound 75 on refluxing with trifluoroacetic acid isomerized to form exocyclic trans-compound 76. It was reported that 1,4-di(arylthiol)-2-butyne derivatives only afforded usual $\mathrm{Hg}$ (II)-salt-mediated hydrated products instead of cyclized thiochromene derivatives. Balasubramanian et al. had performed a mercuric-oxide-mediated cyclization of 1,6-di(aryloxy)-2,4-hexadiyne derivatives 77 to get bichromene derivatives 78 (Scheme 25) [77].

A $\mathrm{HgCl}_{2}$-induced cyclization also takes place for acetylenic silyl enol ether derivative $\mathbf{7 9}$ forming carbocyclic compounds

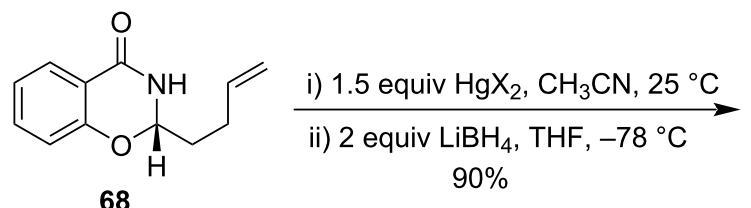<smiles>[CH][C@@]12CC[C@@H](C)N1C(=O)c1ccccc1O2</smiles>

$69 a$<smiles>[CH]C1CC[C@]2([CH])Oc3ccccc3C(=O)N12</smiles><smiles>C=CCCCC1NC(=O)c2ccccc2O1</smiles>
i) 1.5 equiv $\mathrm{HgX}_{2}, \mathrm{CH}_{3} \mathrm{CN}, 25^{\circ} \mathrm{C}$

ii) 2 equiv $\mathrm{LiBH}_{4}, \mathrm{THF},-78^{\circ} \mathrm{C}$ $86 \%$<smiles>C[C@H]1CCC[C@@H](C)Oc2ccccc2C1=O</smiles>

$69 b$

12.4:1<smiles>CC1CCC[C@H]2Oc3ccccc3C(=O)N12</smiles>

$\mathrm{HgX}_{2}=\mathrm{Hg}(\mathrm{OAc})_{2} / \mathrm{Hg}(\mathrm{TFA})_{2}(1: 1)$

71b

Scheme 24: $\mathrm{Hg}(\mathrm{OAc})_{2} / \mathrm{Hg}(\mathrm{TFA})_{2}$-promoted cyclization of salicylamide-derived amidal auxiliary derivatives.

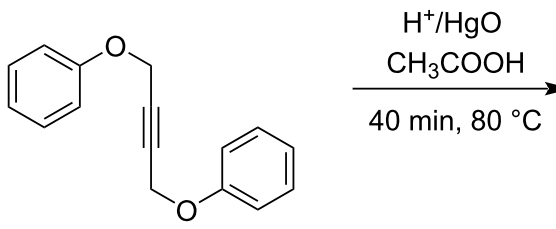

72<smiles>Clc1ccc(OCC#CCSc2ccc(Cl)cc2)cc1</smiles>

74<smiles>Cc1ccc(OCC#CC#CCOc2ccc(C)cc2)cc1</smiles>

77

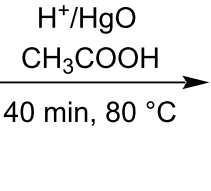
$\mathrm{CH}_{3} \mathrm{COOH}$ $25{ }^{\circ} \mathrm{C}$<smiles>C1=C(COc2ccccc2)c2ccccc2OC1</smiles>

$73,60 \%$<smiles>Clc1ccc(SCC2=CCOc3ccc(Cl)cc32)cc1</smiles>

$75,24 \%$<smiles>Clc1ccc(S/C=C2\CCOc3ccc(Cl)cc32)cc1</smiles>

76<smiles>Cc1ccc2c(c1)OCC=C2C1=CCOc2cc(C)ccc21</smiles>

$78,61 \%$ 


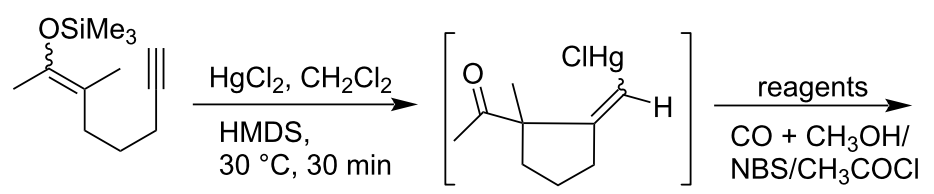

79

80

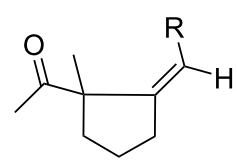

81

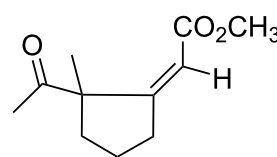

81a, $79 \%$

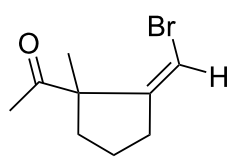

81b, $77 \%$

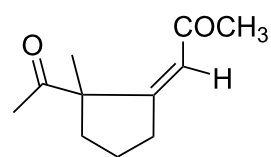

81c, $75 \%$

Scheme 26: $\mathrm{HgCl}_{2}$-induced cyclization of acetylenic silyl enol ether derivatives.

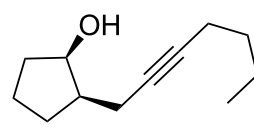

82

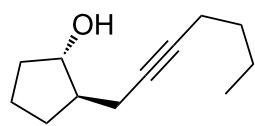

84

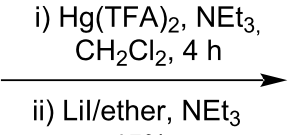

$45 \%$

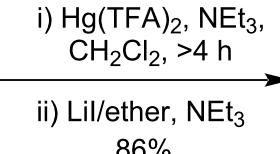

$86 \%$

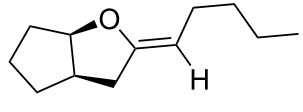

83

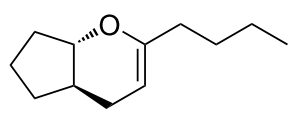

85

Scheme 27: Synthesis of exocyclic and endocyclic enol ether derivatives.

$\mathbf{8 1}$ with good yields via intermediate $\mathbf{8 0}$ [78]. The cyclization of compounds 79 undergo regioselective addition with the triple bond in exocyclic alkene position leading to the formation of $\alpha$-mercury ketone $\mathbf{8 0}$, which were later functionalized by electrophilic addition (Scheme 26).

Schwartz et al. developed a new route for the synthesis of exocyclic enol ether $\mathbf{8 3}$ and endocyclic enol ether $\mathbf{8 5}$ involving a $\mathrm{Hg}$ (II)-induced cyclization of acetylenic alcohols $\mathbf{8 2}$ and $\mathbf{8 4}$, respectively [79]. This work revealed that the regioselectivity of the $\mathrm{Hg}$ (II) addition to the alkyne may be influenced by diastereomers; in the case of cis-isomer $\mathbf{8 2}$ exocyclic enol ether $\mathbf{8 3}$ was formed while for trans-isomer $\mathbf{8 4}$ the reaction takes place with a much slower rate yielding endocyclic enol ether $\mathbf{8 5}$ as the only product (Scheme 27) [79].

trans-Acetylenic alcohol 86 on treatment with $\mathrm{HgCl}_{2}$ ( 0.5 equiv) in presence of $N$-bromosuccinimide (NBS) undergoes cyclization yielding stable bromo alkenes 87 (Scheme 28) $[80,81]$.

Atta et al. reported the specific cyclization of ethynyl phenols 88 in presence of $\mathrm{HgCl}_{2}$ at ambient temperature yielding benzo-

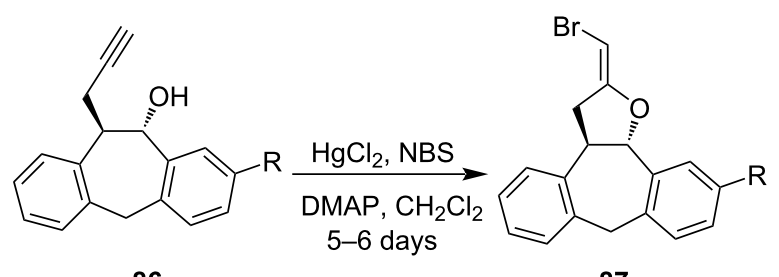

86<smiles>BrC=C1CC2c3ccccc3Cc3ccccc3C2O1</smiles>

$87 a, 91 \%$

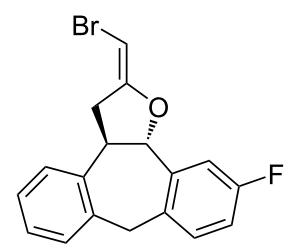

$87 \mathrm{~b}, 88 \%$

Scheme 28: Cyclization of trans-acetylenic alcohol by treatment with $\mathrm{HgCl}_{2}$.

furan derivatives 89. They had reported that the electron-withdrawing electronic effect at the aromatic ring promotes the cyclization reaction, whereas there is no cyclization in the absence of the withdrawing group (Scheme 29) [82]. 
<smiles>[R]C#Cc1cc([N+](=O)[O-])ccc1O</smiles>

$89 a, 95 \%$<smiles>[R]c1oc2ccc([N+](=O)[O-])cc2c1CCl</smiles>

89<smiles>O=[N+]([O-])c1ccc2oc(-c3ccccc3)c(Cl)c2c1</smiles>

$89 b, 93 \%$
Scheme 29: Synthesis of benzofuran derivatives in presence of $\mathrm{HgCl}_{2}$.

Larock et al. had performed the mercuration of 4-hydroxy-2alkyn-1-ones 90 with $\mathrm{HgCl}_{2}$ to get furylmercurials 91 via synaddition of acetylene, which on carbonylation yielded the furancontaining carbonyl compound 92 (Scheme 30) [83]. It was proposed that initially mercuration of acetylene bonds via mercurinium like ions or $\pi$-complex takes place. Then the structure was stabilized through hydrogen bonding between alcohol and carbonyl groups (path a) or by hemiketal formation (path b).
Thus, the chloride ion attacks from the frontside, producing synaddition molecules that, upon dehydration, formed furan rings.

Later they had reported similar mercuration of arylacetylenes to synthesize a broad spectrum of heterocycles, namely benzofurans, benzothiophenes, isocoumarins, chromones, benzopyrans, 1,2-dihydronaphthaIenes, coumarins, and coumestan including some physiologically active heterocyclic natural products like flavones [84]. In the presence of $\mathrm{Hg}(\mathrm{OAc})_{2}$ in acetic acid, simple cyclization of ortho-substituted arylacetylenes $\mathbf{9 3}, \mathbf{9 5}$, and 97 yielded benzofurans 94, benzothiophenes 96, and indoles 98, respectively. When the carbonyl group was introduced between an aryl and a methoxy group (99) then six-membered isocoumarin ring $\mathbf{1 0 0}$ was formed, and when a carbonyl group was introduced in between an aryl and an alkyne group (101), chromone derivatives $\mathbf{1 0 2}$ were formed. On the introduction of the methylene moiety in between the aryl and methoxy group, 103 yielded isofuran derivatives $\mathbf{1 0 4}$ due to the change in regioselectivity during the cyclization. Dihydronapthalenes $\mathbf{1 0 6}$ were synthesized by cyclization of the corresponding methoxyarylalkyne derivative $\mathbf{1 0 5}$ (Scheme 31).

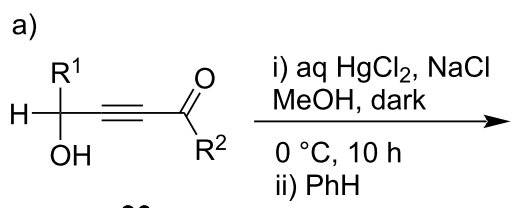

90

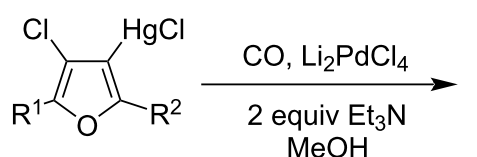

91<smiles>[R]c1o[R]c(Cl)c1C(=O)OC</smiles><smiles>Cc1oc(CO)c(CCl)c1Cl</smiles><smiles>Cc1oc(C)c(CCl)c1Cl</smiles>

91b, $63 \%$<smiles>COC(=O)c1c(C)oc(C)c1Cl</smiles>

92a, $97 \%$

b)

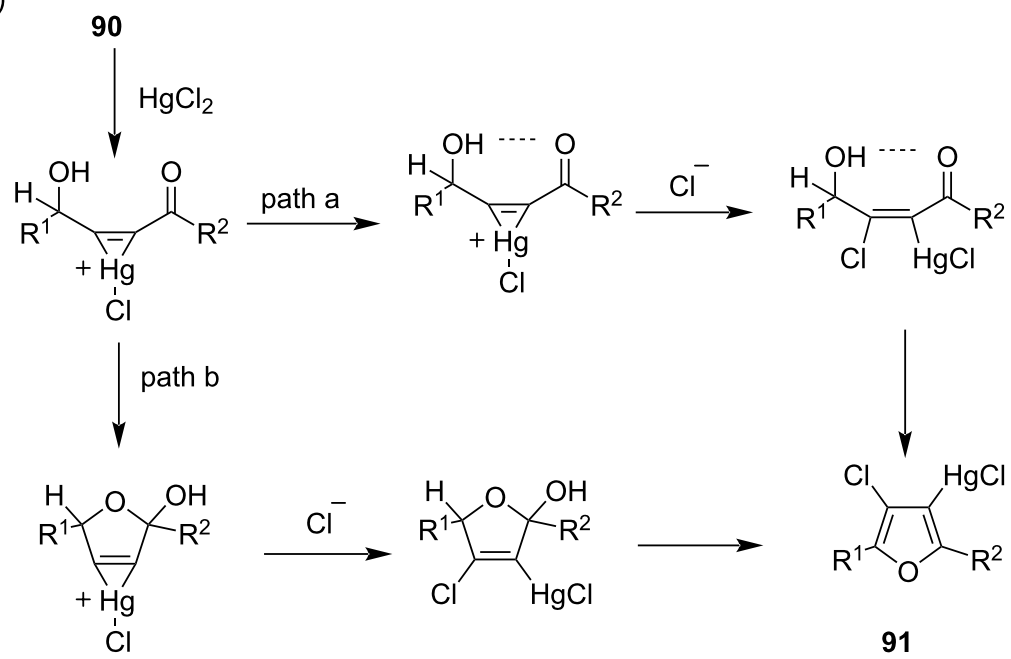


<smiles>CCCCCCCCCCCCCCCCCC</smiles>

93<smiles>CCCCCCCCCCCC</smiles>

95

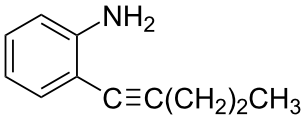

97<smiles>CCCCCCC#Cc1ccccc1C(=O)OC</smiles>

99<smiles>COc1ccccc1C(=O)C#CCc1ccccc1</smiles>

01<smiles>CCCCCCCCc1ccccc1COC</smiles>

103<smiles>CCCC#CCc1cccc(OC)c1</smiles>

105<smiles>CCCCc1oc2ccccc2c1CCl</smiles>

94<smiles>CCCc1sc2ccccc2c1CCCC(=O)OCC(=O)OCc1ccccc1</smiles>

96<smiles>O=C(O)CCCC(=O)OCCO</smiles><smiles>CCCCc1cc2ccccc2[nH]1</smiles>

98<smiles>O=C(O)CCCOC(=O)C(=O)O</smiles>
$65 \%$<smiles>CCCCc1oc(=O)c2ccccc2c1Cl</smiles>
100<smiles>O=C(O)CCCOC(=O)CCC(=O)O</smiles>

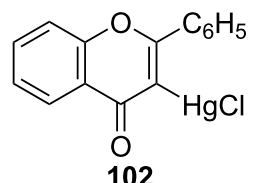

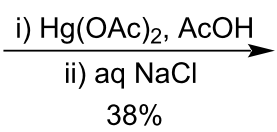

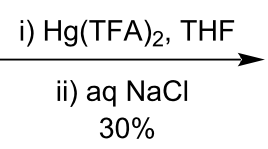
$30 \%$<smiles>CCCCCC(C=O)=C1OCc2ccccc21</smiles>

104<smiles>CCCC1=C(C)C(Cl)=C(C)c2ccc(OC)cc2C1</smiles>

106

Scheme 31: Cyclization of arylacetylenes to synthesize carbocyclic and heterocyclic derivatives.

In 2005, Ghorai et al. reported the synthesis of a mixture of 6-membered as well as 5-membered heterocyclic compounds through a $\mathrm{Hg}(\mathrm{II})$-salt-promoted unique cyclization-rearrangement reaction [85]. They had performed the $\mathrm{HgCl}_{2}$-promoted cyclization of $O$-propargyl glycolaldehyde dithioacetals 107 via their dithioketals and dithioacetals to synthesize six-membered heterocycles 108 and 109 (Scheme 32). Five-membered dihydrofuryl aldehydes were also isolated as minor products in some examples.

Following a similar protocol, Biswas et al. later published the $\mathrm{HgCl}_{2}$-mediated cyclization reaction of tethered alkynedithioacetals 110 to provide six- and five-membered carbocyclic and heterocyclic derivatives 111 and 112, respectively. They had observed that the formation of five-membered rings $(\mathbf{1 1 2} \mathbf{a}-\mathbf{c})$

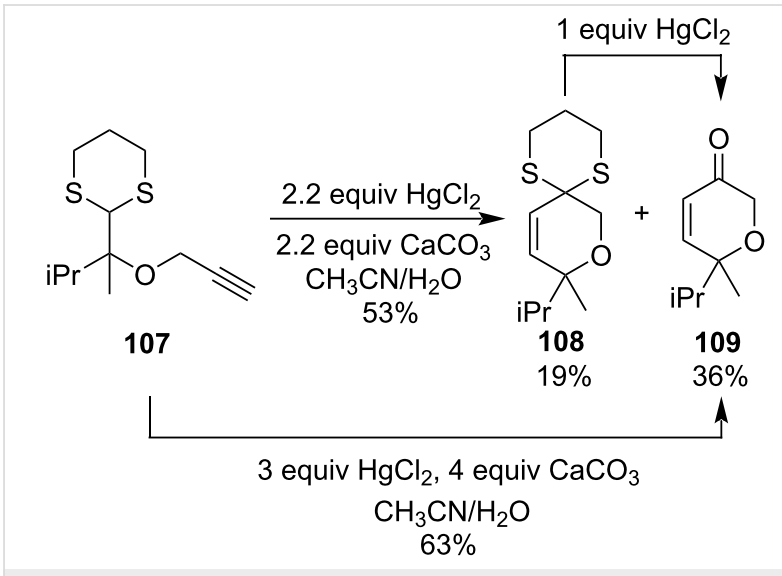

Scheme 32: $\mathrm{Hg}(\mathrm{II})$-salt-promoted cyclization-rearrangement to form heterocyclic compounds. 
was preferred when substitutents were present at the alkyne terminus, whereas six-membered rings $(\mathbf{1 1 1 a}, \mathbf{b})$ formed predominantly in case of unsubstituted alkyne dithioacetals (Scheme 33) [86]. They had reported the plausible mechanism for the formation of a six-membered pyranose ring follows 'path a,' while for the formation of five-membered pyrrolidine derivatives 'path $\mathrm{b}$ ' was followed.

\section{Cyclization involving allenes $(>\mathrm{C}=\mathrm{C}=\mathrm{C}<$ )}

Apart from alkenes/alkynes, there are also examples where cyclization takes place involving allene functionalities. Some of the examples are discussed below.

Balasubramanian et al. reported the cyclization of aryl allenic ethers 113 on treatment with $\mathrm{Hg}(\mathrm{OTf})_{2}$. Compound 113 reacted with 1.1 equiv of $\mathrm{Hg}(\mathrm{OTf})_{2}$ at room temperature followed by reduction with alkaline $\mathrm{NaBH}_{4}$ leading to the formation of benzopyran derivatives $\mathbf{1 1 4}$ and $\mathbf{1 1 5}$. The ratio of the formation of products depends on the temperature and time of the reaction (Scheme 34) [87].

Devan et al. had developed similar types of $\mathrm{Hg}(\mathrm{TFA})_{2}$-mediated cyclizations of allene $\mathbf{1 1 6}$ at low temperature followed by reduction with alkaline $\mathrm{NaBH}_{4}$ to form cyclized product 117 in moderate yield [88]. The reaction was believed to proceed through $\mathrm{Hg}(\mathrm{II})$ ion-promoted electrophilic cyclization (Scheme 35).

\section{Cyclization involving catalytic $\mathrm{Hg}$ (II) salts Cyclization involving alkenes $(>\mathrm{C}=\mathrm{C}<)$}

Apart from the stoichiometric amount used in cyclization, there is abundant literature where a catalytic amount of $\mathrm{Hg}$ (II) salt was employed for cyclization reactions between nucleophiles and unsaturated bonds.

a)

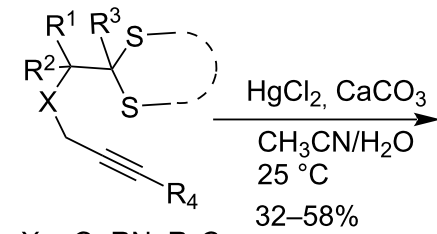<smiles>[R]C1=C([R])C([R])=C([R])C(=O)C1</smiles><smiles>[R]C(=O)C1=C([R])C([R])([R])[X]1</smiles>

$$
X=\mathrm{O}, \mathrm{RN}, \mathrm{R}_{2} \mathrm{C}
$$

$\mathrm{R}^{4}=\mathrm{H}$, major

$\mathrm{R}^{4} \neq \mathrm{H}$, major<smiles>CCOC(=O)C1(OCC)CC=CC(=O)C1</smiles><smiles>O=C1C=CCN([123I])C1</smiles>

$111 b, 41 \%$<smiles>CC(C)C1(C)C=C(C(=O)c2ccccc2)CO1</smiles><smiles>COc1ccc(C2C=C(C(C)=O)CO2)cc1</smiles><smiles>O=C(C1=CCN([125I])C1)c1ccccc1</smiles>

$112 a, 37 \%$

112b, $34 \%$ $112 \mathrm{c}, 38 \%$

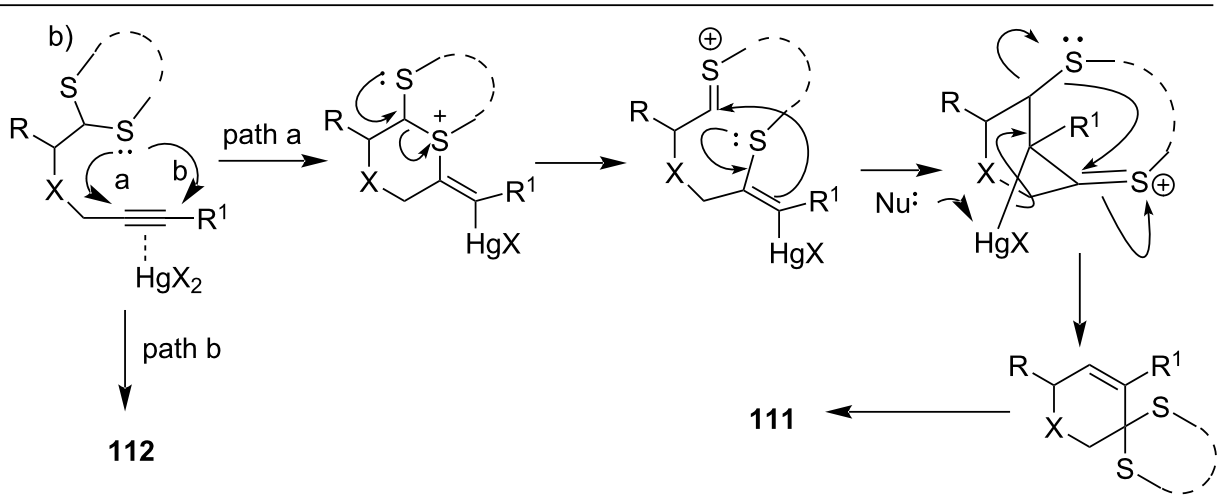




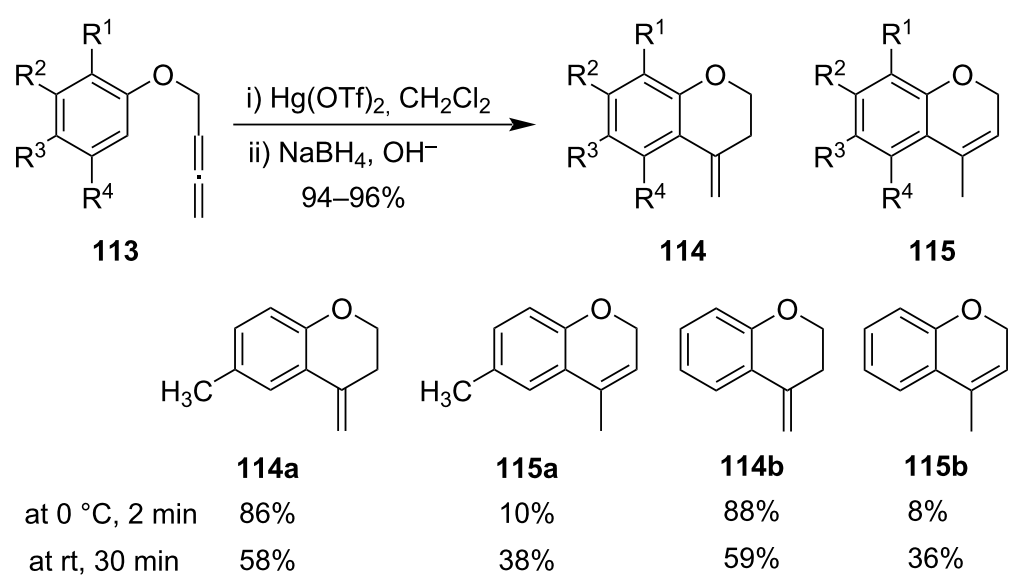

Scheme 34: Cyclization of aryl allenic ethers on treatment with $\mathrm{Hg}(\mathrm{OTf})_{2}$.<smiles>C=C=CCN(C#N)c1ccccc1</smiles>

116

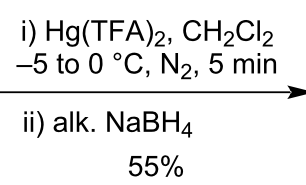<smiles>C=C1CCN(C#N)c2ccccc21</smiles>

117
Scheme 35: $\mathrm{Hg}(T F A)_{2}$-mediated cyclization of allene.

The synthesis of fused polycyclic ethers by the treatment of a catalytic amount of $\mathrm{Hg}(\mathrm{TFA})_{2}$ with suitable starting material was demonstrated by Tan et al. [89]. They had reported a $\mathrm{Hg}$ (II)-catalyzed intramolecular trans-etherification reaction of 2-hydroxy-1-( $\gamma$-methoxyallyl)tetrahydropyrans $\mathbf{1 1 8}$ and $\mathbf{1 2 0}$ to the corresponding bicyclic dihydropyrans 119 and 121, respectively (Scheme 36).

Later, Namba et al. reported the synthesis of racemic vinylindoline derivatives $\mathbf{1 2 3}$ from $\mathrm{N}$-tosylanilinoallylic alcohol derivative 122 by using $1-2 \mathrm{~mol} \%$ of $\mathrm{Hg}(\mathrm{OTf})_{2}$ in $\mathrm{CH}_{2} \mathrm{Cl}_{2}$ at room temperature [90]. An asymmetric synthesis of vinylindoline derivatives $\mathbf{1 2 5}$ was achieved by utilizing chiral ligands like chiral binaphane (Scheme 37) [91]. They had observed that the formation of six- and seven-membered rings required elevated temperatures. Subsequently, the same group studied the cyclization of arylene $\mathbf{1 2 6}$ to furnish naphthalene derivative 127. The plausible mechanism for the formation of compound $\mathbf{1 2 7}$ proceeded consecutively with $\pi$-complex formation, Friedel-Crafts type addition, deprotonation, and finally protonation of alcohol for the elimination of water to get the final product [92].

$\mathrm{A} \mathrm{Hg}(\mathrm{OTf})_{2}$-mediated cyclization was utilized for the synthesis of 1,4-dihydroquinoline $\mathbf{1 2 9}$ possessing a quaternary carbon center from 128 [93]. The reaction was reported via a sevenmembered bicyclic hemiaminal as mentioned in the mechanism. This catalytic rearrangement protocol was successfully applied for the construction of complex carbon frameworks from various tosylanilinoallyl acetals. $4 H$-Chromene derivatives were also synthesized starting from phenol derivatives (Scheme 38).<smiles>CO/C=C/C[C@H]1OC(CO[AsH])C(Br)[C@H](O)[C@H]1O</smiles>

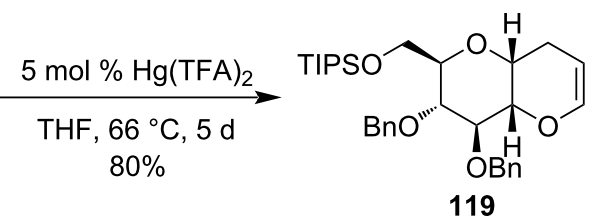<smiles>CO/C=C/CC1OC(CO[SH](=O)(F)F)[C@H](O)[C@H](O)C1O</smiles>

120

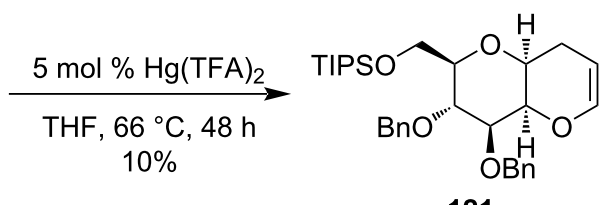

Scheme 36: $\mathrm{Hg}$ (II)-catalyzed intramolecular trans-etherification reaction of 2-hydroxy-1-(y-methoxyallyl)tetrahydropyran derivatives. 
a)

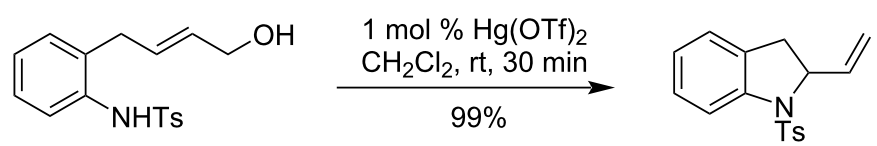

122

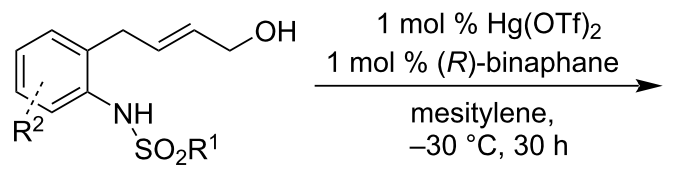

$124 \mathrm{R}^{1}=\mathrm{Me}, \mathrm{Et}, \mathrm{iPr}, t-\mathrm{Bu}, \mathrm{Ph}$, $60-99 \%$

$\mathrm{R}^{2}=$ alkyl, $\mathrm{OMe}, \mathrm{Br}, \mathrm{H}$
123<smiles>[R]OS(=O)N1c2ccccc2CC1C=C</smiles>

up to $99 \%$ ee

125

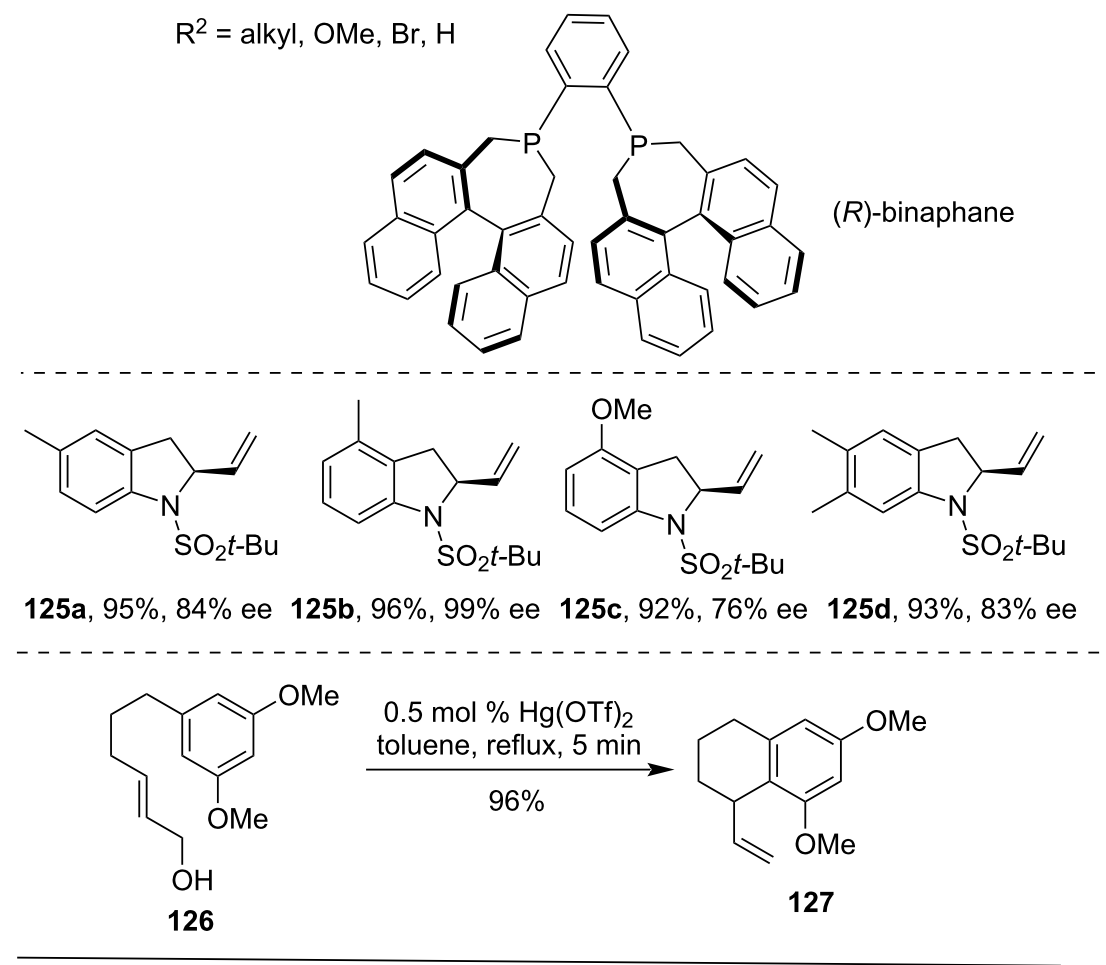

b)<smiles>COc1cc(CCCCCOCCO)cc(OC)c1</smiles><smiles>COc1cc2c(c(OC)c1)C(C(O)O)CCC2</smiles>
$\stackrel{\mathrm{TfOH}}{\longrightarrow}$<smiles>COc1cc(OC)c2ccc(O)cc2c1</smiles>

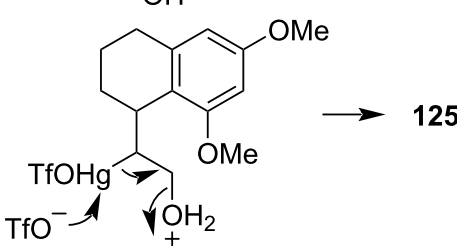

Scheme 37: a) Cyclization of alkene derivatives by catalytic $\mathrm{Hg}(\mathrm{OTf})_{2}$ salts and b) mechanism of cyclization.

\section{Cyclization involving alkynes $(-\mathrm{C} \equiv \mathrm{C}-)$}

Marson et al. had developed the synthesis of substituted furans 133a-c promoted by catalytic use of $\mathrm{Hg}$ (II) salt through cyclization of secondary and tertiary 1-alkynyl-2,3-epoxyalcohols 131a [94]. This is an example of a $\mathrm{Hg}(\mathrm{II})$-salt-catalyzed rear- rangement of 1-alkynyl-2,3-epoxy alcohols to substituted furans. The furan 133a was formed by dehydration of intermediate 132a through the corresponding oxonium cation. When $\mathrm{R}^{3}$ is an alkyl group, direct dehydration was not possible because of blocking. Later they reported a similar transformation of 


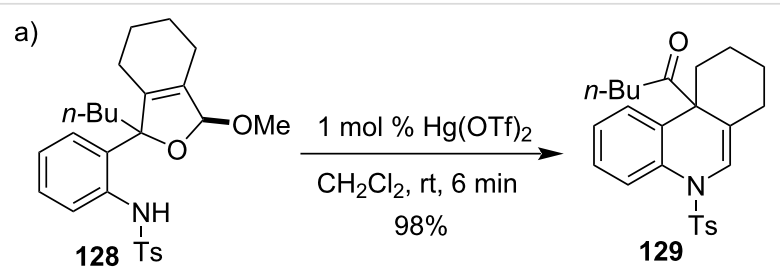

b)

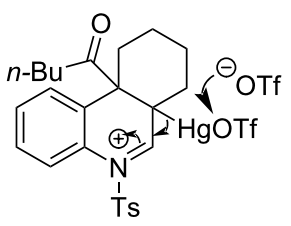

Scheme 38: a) Synthesis of 1,4-dihydroquinoline derivatives by $\mathrm{Hg}(\mathrm{OTf})_{2}$ and $\mathrm{b}$ ) plausible mechanism of formation. thiiranes to provide a wide variety of substituted thiophenes. They had synthesized substituted thiophenes 133b starting from thiiranes 131b via cyclization utilizing the catalytic amount of $\mathrm{HgO}$ and dil. $\mathrm{H}_{2} \mathrm{SO}_{4}$ at room temperature [95]. Initially, the $\mathrm{Hg}$ (II)-salt-catalyzed the formation of intermediate 132b which further proceeded by dehydration to yield thiophenes $\mathbf{1 3 3 b}$ as the final product (Scheme 39).

Starting with 1-alkynyl-2,3-epoxy alcohols 135, Marson et al. had reported a $\mathrm{Hg}(\mathrm{II})$-salt-catalyzed rearrangement to produce 2,3-disubstituted-2,3-dihydropyranone derivatives 136. The stereochemistry of substituents at 2,3-positions of 2,3-dihydropyranone 136 was controlled by cis- and trans-configuration of the epoxide of starting materials (Scheme 40) [96].
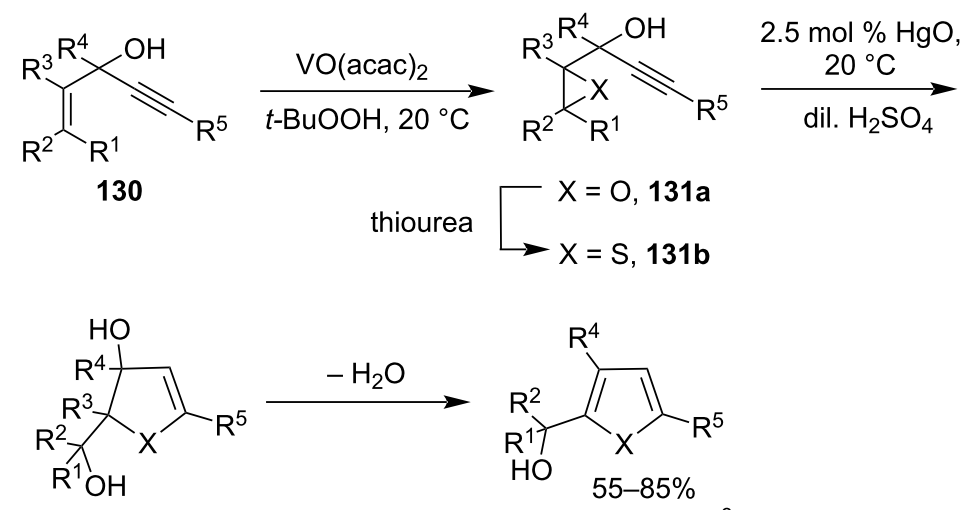

132a, $X=0$

133a, $X=O R^{3}=H$

$132 b, X=S$

133b, $X=S$

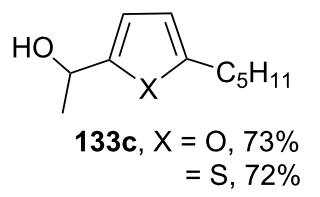<smiles>Cc1cc(-c2ccccc2)sc1C(C)O</smiles><smiles>CC(O)c1ccc(CO)s1</smiles>

$133 e, 66 \%$

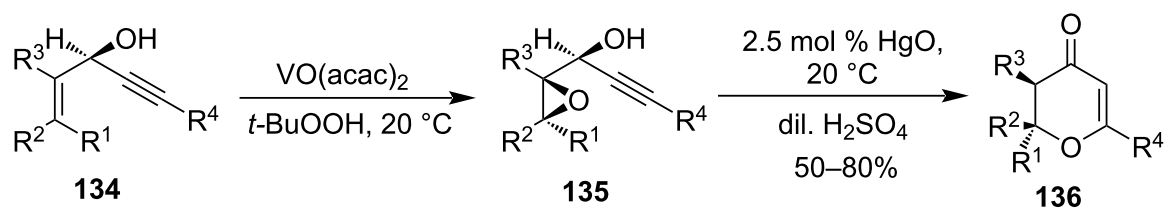<smiles>O=C1C=C(c2ccccc2)OCC1c1ccccc1</smiles>

$136 a, 80 \%$

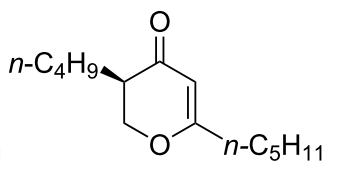

136b, $67 \%$<smiles>CCCCCCCCCCCCCCCCC</smiles>

136c, $56 \%$<smiles>CC[C@H]1OC(CO)=CC(=O)[C@H]1C</smiles>

136d, $57 \%$ 
Several unsaturated lactones had been synthesized from alkynoic acids via $\mathrm{Hg}$ (II)-salt-catalyzed cyclization reaction. For example, simple 4-pentynoic acid derivatives $\mathbf{1 3 7}$ afforded $\gamma$-methylene butyrolactones $\mathbf{1 3 9}$ in good yields via the formation of organomercural compounds $\mathbf{1 3 8}$ using catalytic mercuric oxide, mercuric acetate, or mercuric trifluoroacetate as shown in Scheme 41 [97].

Alkyne carboxylic acids also undergo oxymercuration reactions to form furan- and pyran-like derivatives. When $\gamma$-alkyne carboxylic derivative $\mathbf{1 4 0}$ was refluxed with $\mathrm{HgO}$ the cyclization took place to give product $\mathbf{1 4 1}$ in almost quantitative yields $[98,99]$. Compound 142 under refluxing conditions gave spirocyclic compound $\mathbf{1 4 3}$ as the exclusive product (Scheme 42) [99]. Propargylic triols 144 undergo $\mathrm{Hg}(\mathrm{OTf})_{2}$-catalyzed cyclization reaction, to produce monounsaturated spiroketal 145 .
Finally in the case of 1,2-dihydroxy-3-alkynes 146 comparable reaction conditions leads to the formation of 2.5-disubstituedfuran 147 rather than mono-unsaturated spiroketals [100].

Interestingly when 1.4-dihydroxy-5-alkyne derivatives were subjected to a $\mathrm{Hg}(\mathrm{OTf})_{2}$-catalyzed cyclization then oxacyclization takes place to form tetrahydropyran derivatives (Scheme 43) [101]. Later it was shown that alkynyl diol 150 when treated with $20 \mathrm{~mol} \% \mathrm{Hg}(\mathrm{OTf})_{2}$ followed by $\mathrm{Et}_{3} \mathrm{SiH}$ afforded bispyranoyl ketone $\mathbf{1 5 1}$, but when $\mathrm{Hg}(\mathrm{OTf})_{2}$ was increased (1 equiv) then fused pyran-oxocane derivative $\mathbf{1 5 2}$ was isolated [102].

Six-membered morpholine derivatives were also synthesized by catalytic $\mathrm{Hg}$ (II)-salt-induced cyclization. Yamamoto and co-workers published the intermolecular cyclization of alkynyl-<smiles>[R]C#CCC([R])C(=O)O</smiles><smiles>C=C1CCC(=O)O1</smiles>

139a, $75 \%$<smiles>CC=C1CC(c2ccccc2)C(=O)O1</smiles>

139b, $76 \%$<smiles>O=C1CC/C(=C/Br)O1</smiles>

139c, $60 \%$<smiles>O=C1CCC(=CCl)O1</smiles>

139d, $49 \%$

Scheme 41: Hg(II)-salt-catalyzed cyclization of alkynoic acids<smiles>C#CCCC(=O)O</smiles>

140<smiles>O=C(O)CCC#CCCCO</smiles>

142<smiles>CC(C)(O)C[C@@](C)(O)C#CCCCCO</smiles>

144<smiles>OCCCC#CC(O)(CO)CO</smiles>

146
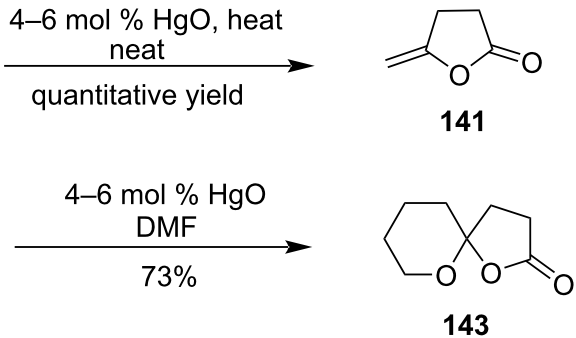

$10 \mathrm{~mol} \% \mathrm{Hg}(\mathrm{OTf})_{2}$
$\mathrm{CH}_{3} \mathrm{CN}, \mathrm{rt}, 5 \mathrm{~min}$<smiles>CC1=C[C@@]2(CCCCO2)OC(C)(C)C1</smiles>

145

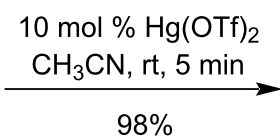

$98 \%$<smiles>OCCCc1cc(CO)co1</smiles>

147 
<smiles>OCCCC(O)C#CCCOCc1ccccc1</smiles>

148

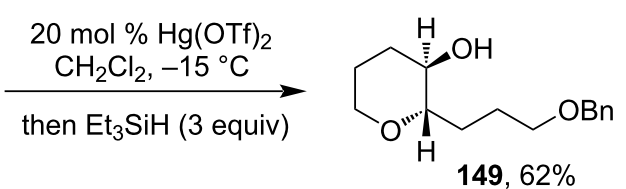

$149,62 \%$<smiles>O[C@H](C#CCC[18OH])CC[C@H]1OCCC[C@H]1O</smiles>

150

1 equiv $\mathrm{Hg}(\mathrm{OTf})_{2}$, then $\mathrm{Et}_{3} \mathrm{SiH}$ (3 equiv) $\mathrm{CH}_{2} \mathrm{Cl}_{2},-15^{\circ} \mathrm{C}$<smiles>OCCC[C@@H]1C[C@H](O)CC[C@H]2OCCC[C@H]2O1</smiles>

$152,27 \%$
$20 \mathrm{~mol} \% \mathrm{Hg}(\mathrm{OTf})_{2}$ $\mathrm{CH}_{2} \mathrm{Cl}_{2},-15^{\circ} \mathrm{C}$

then $\mathrm{Et}_{3} \mathrm{SiH}$ (3 equiv)<smiles>O=C(CCOc1ccccc1)C[C@@H]1CC[C@@H]2OCCC[C@H]2O1</smiles>

$151,72 \%$

Scheme 43: Hg(II)-salt-mediated cyclization of 1,4-dihydroxy-5-alkyne derivatives.

carboxylic acid $\mathbf{1 5 3}$ to produce 6-membered morpholine type ring compound 154 and compound 155 [103]. The stereochemistry of the chiral amino acid was not conserved in the cyclized product hence it leads to the formation of racemic products with moderate yields (Scheme 44).

1,6-Enynes 156 underwent smooth hydroxylative carbocyclization in the presence of catalytic $\mathrm{Hg}(\mathrm{OTf})_{2}$. As an example, 3-methylene five-membered cyclic derivatives 157 were synthesized by Nishizawa et al. via the $\mathrm{Hg}(\mathrm{OTf})_{2}$-catalyzed hydroxylative carbocyclization of 1,6-enyne $\mathbf{1 5 6}$ (Scheme 45) [104]. It was observed that from 1,7-enynes, six-membered rings were formed in low to moderate yield while from 1,8-enynes, uncyclized hydrated products were isolated. as major products along with different byproducts.

In a $\mathrm{Hg}(\mathrm{OTf})_{2}$-catalyzed process, 1,6-allenynes $\mathbf{1 5 8}$ were cycloisomerized to generate allenenes $\mathbf{1 5 9}$ in moderate to good yield (Scheme 46) [105]. However, depending on the substituents, allenene and/or unexpected triene were produced as a main product for disubstituted 1,6-allenynes. It was hypothesized based on experimental evidence that alkynes would first form a $\pi$-complex with $\mathrm{Hg}(\mathrm{OTf})_{2}$, followed by vinylmercuration, demercuration, and eventually isomerizes to allenene.<smiles>[R]C(=O)N(CC#C)C([R])C(=O)O</smiles>

153<smiles>CC(=O)N1C=C(C)OC(=O)[C@H]1CC(C)C</smiles>

$154 a, 40 \%$

\section{$5-10 \mathrm{~mol} \% \mathrm{HgO}$} toluene $100^{\circ} \mathrm{C}$

O<smiles>[R]C(=O)N1C=C(C)OC(=O)C1[R1]</smiles><smiles>[R16]C(=O)N1CC(=C)OC(=O)C1[R16]</smiles>

$27-40 \%$ 


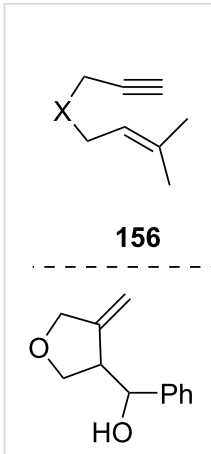

$157 a, 85 \%$
$0.1-10 \mathrm{~mol} \% \mathrm{Hg}(\mathrm{OTf})_{2}$
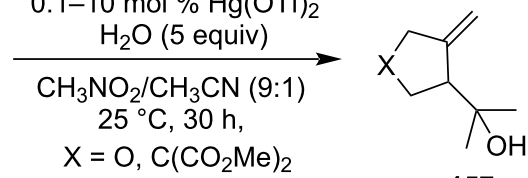

157

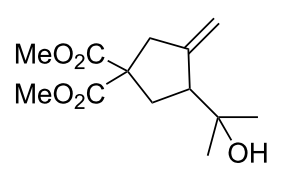

$157 \mathrm{c}, 90 \%$

Scheme 45: $\mathrm{Hg}(\mathrm{OTf})_{2}$-catalyzed hydroxylative carbocyclization of 1,6enyne.

In 2003, a carbocyclization with a catalytic quantity of mercury salt was used to efficiently synthesize dihydronapthalene derivative 161 from exemplifying benzyl derivative 160 [106]. The reported methodology was an example of the $\mathrm{Hg}(\mathrm{OTf})_{2} \cdot(\mathrm{TMU})_{3}$ complex promoting a moderate and efficient procedure for arylalkyne cyclization to directly afford dihydronapthalene derivatives (Scheme 47). Later, Friedel-Crafts type reaction of alkynylfuran 162 and 164 were

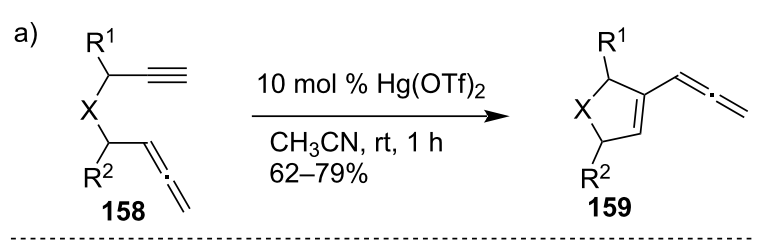

\begin{tabular}{ccc}
$159 \mathrm{~b}, 68 \%$ & $159 \mathrm{c}, 79 \%$ \\
\hline $159 \mathrm{a}, 72 \%$ &
\end{tabular}

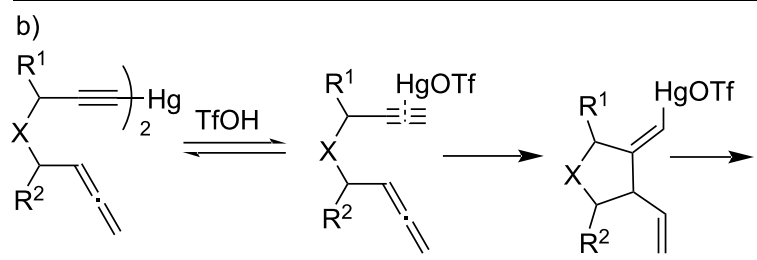

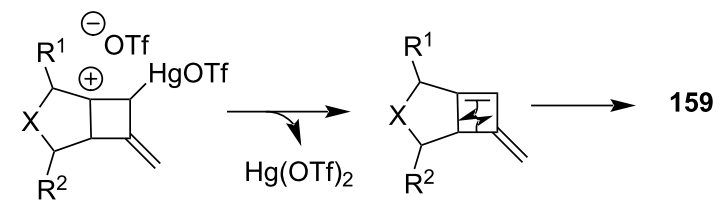

Scheme 46: a) $\mathrm{Hg}(\mathrm{OTf})_{2}$-catalyzed hydroxylative carbocyclization of 1,6-enyne. b) Proposed mechanism. a)<smiles>CCC#CCCc1cc(OC)cc(OC)c1</smiles>

160<smiles>CCC1=CCCc2cc(OC)cc(OC)c21</smiles>

161<smiles>C#CCC(Cc1ccccc1)(Cc1ccc(C)o1)C(OC)C(=O)OC</smiles>

164

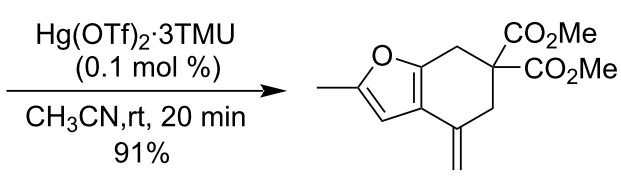

163<smiles>CCC1=CCCCc2oc(C)cc21</smiles>

165

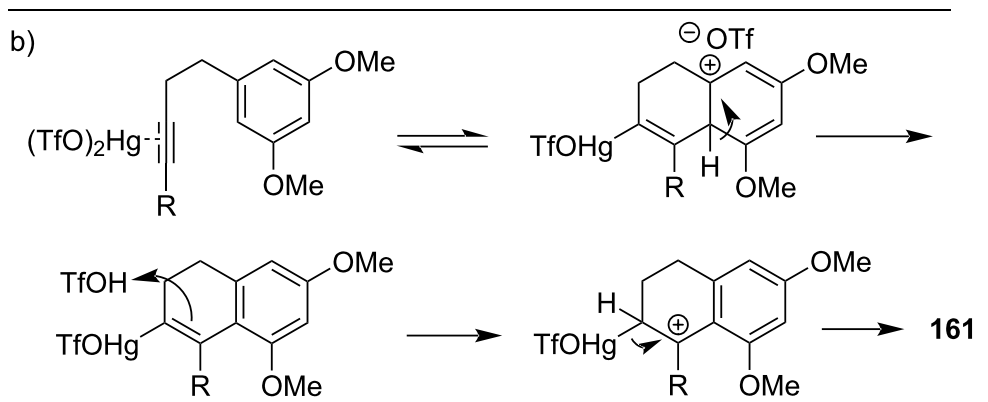


reported in presence of the $\mathrm{Hg}(\mathrm{OTf})_{2} \cdot 0.1 \mathrm{Sc}(\mathrm{OTf})_{3}$ complex $(5 \mathrm{~mol} \%)$ to form six- (163) and seven-membered rings (165) in good yield. For the cyclization at 2-position of the furan the $\mathrm{Hg}(\mathrm{OTf})_{2} \cdot(\mathrm{TMU})_{3}$ complex was used as catalyst [107].

Later it was reported that 1-alkyn-5-ones such as $\mathbf{1 6 6}$ also undergo an effective cyclization reaction to synthesize 2-methylfuran derivatives $\mathbf{1 6 7}$ with high yield in the presence of $\mathrm{Hg}(\mathrm{OTf})_{2}$ as the catalyst under very mild reaction conditions (Scheme 48) [108].

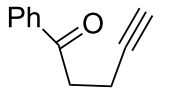

166

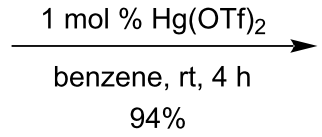

$94 \%$
167

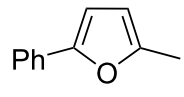

Scheme 48: Cyclization of 1-alkyn-5-ones to 2-methylfuran derivatives.

Cyclization of 6-aminohex-1-yne $\mathbf{1 6 8}$ was performed by catalytic amounts of $\mathrm{Hg}\left(\mathrm{NO}_{3}\right)_{2}$ and generated 2-methylenepiperidine 169 initially, which further isomerizes to form 2-methyl1,2-dehydropiperidine (170, Scheme 49) [109].

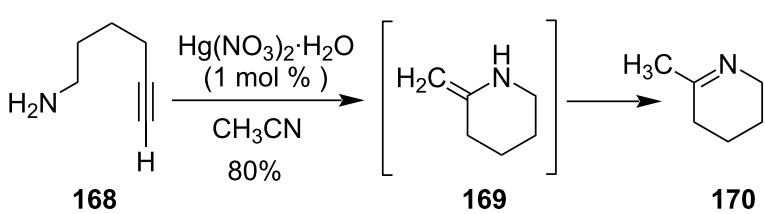

Scheme 49: $\mathrm{Hg}\left(\mathrm{NO}_{3}\right)_{2}$-catalyzed synthesis of 2-methylenepiperidine.

Similarly, in 2007 Kurisaki et al. had also prepared indole derivatives $\mathbf{1 7 2}$ with excellent yields from 2-ethynylaniline derivatives $\mathbf{1 7 1}$ upon the treatment of catalytic amounts of $\mathrm{Hg}(\mathrm{OTf})_{2}$ at room temperature. It was an example of cycloisomerization of 2-ethynylaniline derivatives utilizing mild reaction conditions (Scheme 50) [110].

Rong et al. had demonstrated the $\mathrm{Hg}(\mathrm{II})$-salt-catalyzed enolate umpolung reaction for the efficient synthesis of various 3 -indolinones and 3-coumaranones 174. They had proved that the reaction mechanism proceeds via activation of the alkynyl group with $\mathrm{Hg}(\mathrm{OTf})_{2}$ salt and addition of 2-chloropyridine $\mathrm{N}$-oxide. The resulting activated alkynyl complex was demercurated, followed by the $\mathrm{SN}_{2}$ ' reaction thus formed undergoes demercuration to yield 3-coumaranone (Scheme 51) [111].

Recently, a $\mathrm{Hg}(\mathrm{OTf})_{2}$-catalyzed one-pot cyclization of nitroalkyne $\mathbf{1 7 5}$ and alkyne had been reported to synthesize indole derivatives 176. Based on this strategy, the one-pot
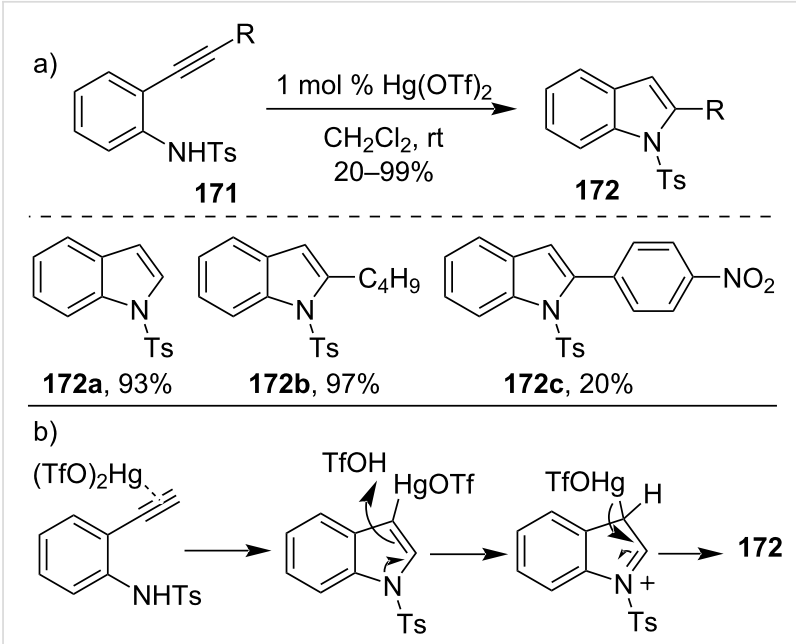

Scheme 50: a) Preparation of indole derivatives through cycloisomerization of 2-ethynylaniline and $b$ ) its mechanism.

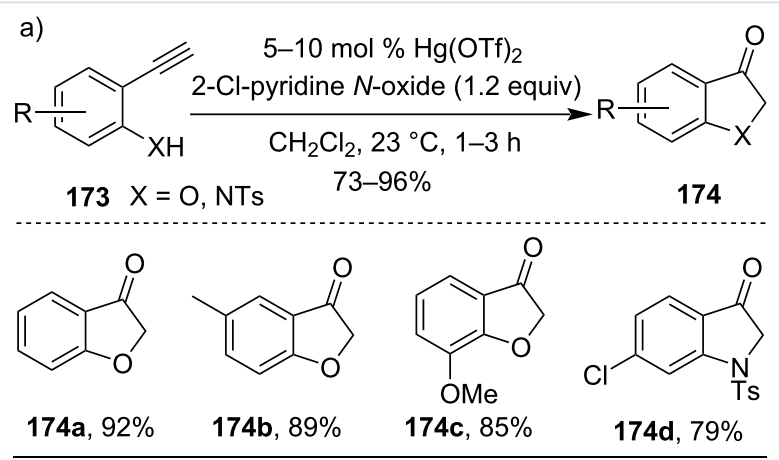

b)

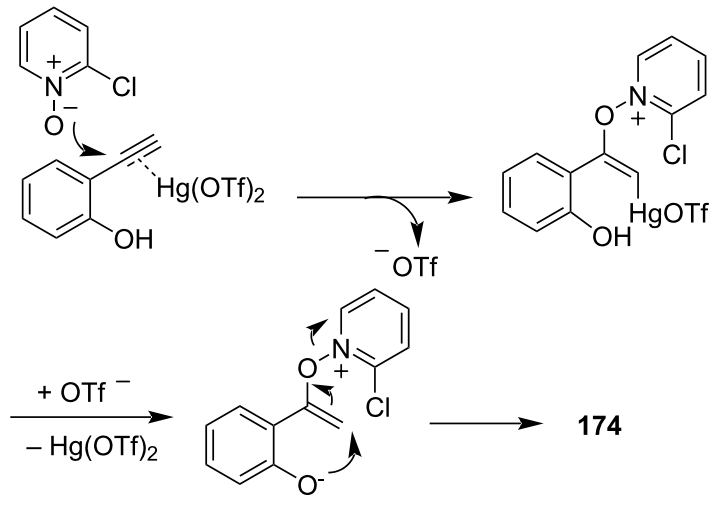

Scheme 51: a) $\mathrm{Hg}(\mathrm{OTf})_{2}$-catalyzed synthesis of 3-indolinones and 3-coumaranones and b) simplified mechanism.

method to synthesize indole derivatives had been developed [112]. Similarly, benzo[c] isoxazole was also formed in excellent yields with high selectivity using this strategy. In these transformations, two $\mathrm{Hg}$-carbene intermediates were proposed to be involved (Scheme 52).

Mercury-catalyzed reactions were also well known for the formation of various complex scaffolds like tricyclic pyrazinones 
a)

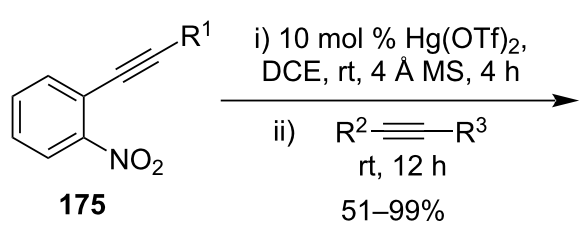<smiles></smiles>

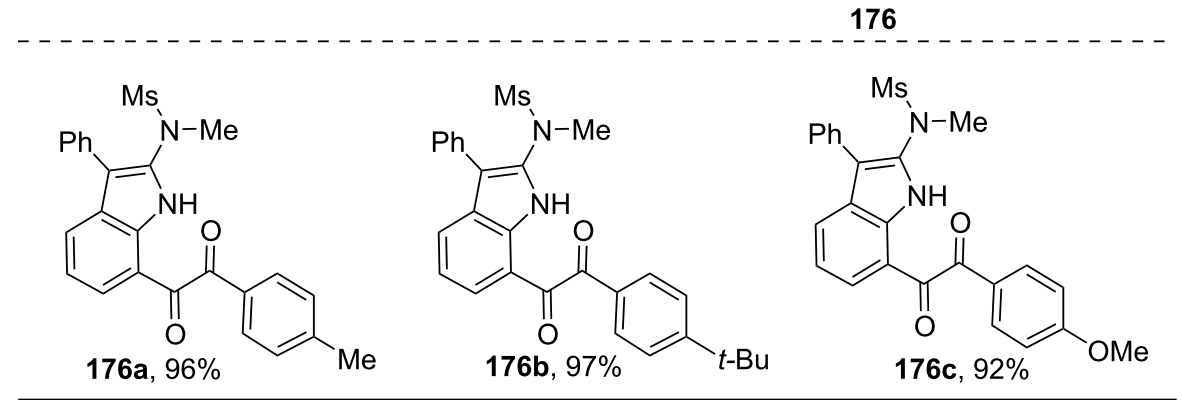

b)
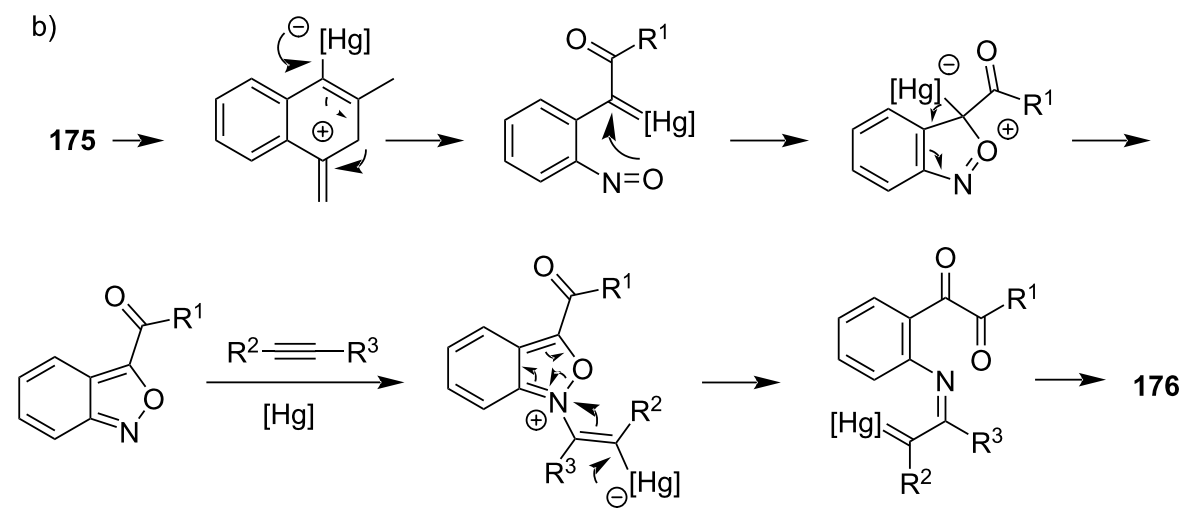

Scheme 52: a) $\mathrm{Hg}(\mathrm{OTf})_{2}$-catalyzed one pot cyclization of nitroalkyne and b) its plausible mechanism.

from the corresponding starting materials. For example, Zhang et al. showed that refluxing anilide $\mathbf{1 7 7}$ in presence of a catalytic amount of $\mathrm{Hg}(\mathrm{OAc})_{2}$ and $90 \%$ formic acid gave the tricyclic heterocyclic scaffold $\mathbf{1 7 8}$ [113]. It involved a two-step process with the rearrangement of the primary cyclization products (Scheme 53).<smiles>[R]NC(=O)c1nc2ccccc2c(=O)n1CC#C</smiles>

177<smiles>Cc1cn2c(=O)c3ccccc3nc2c(=O)n1-c1ccccc1</smiles>

$178 a, 60 \%$<smiles>[R]n1c(C)cn2c(=O)c3ccccc3nc2c1=O</smiles>

178 
In 2013, Lin et al. reported a $\mathrm{Hg}$ (II) chloride-mediated cyclization reaction of 2-alkynylphenyl alkyl sulfoxide $\mathbf{1 7 9}$ to synthesize benzothiophene derivatives 180 with good yields [114]. In this case, the reaction was believed to proceed via the initial formation of metal carbenoids followed by a sequential $\mathrm{C}-\mathrm{H}$ insertion and then oxidation (Scheme 54). This methodology was later successfully utilized for the total synthesis of raloxifene and benzo $[b]$ thiophene derivatives [115].<smiles>O=[SH](=O)c1ccccc1C#CF</smiles>

179
$50-72 \%$

180
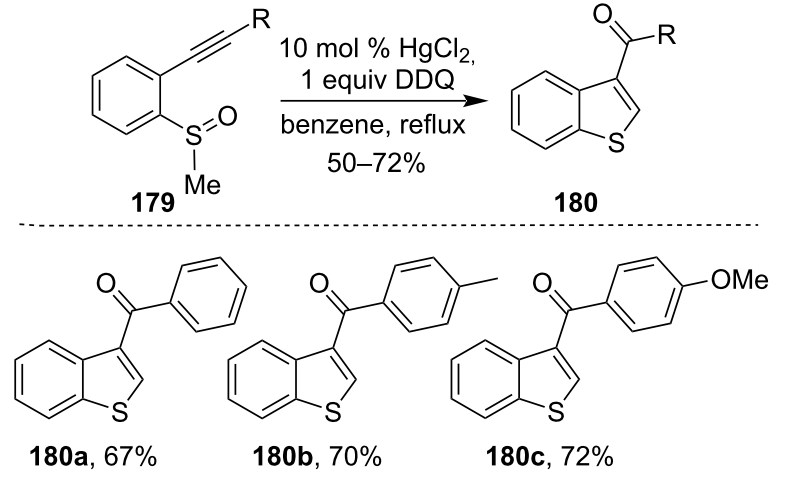

Scheme 54: $\mathrm{HgCl}_{2}$-mediated cyclization of 2-alkynylphenyl alkyl sulfoxide.

\section{Cyclization involving allenes $(>\mathrm{C}=\mathrm{C}=\mathrm{C}<$ )}

$\mathrm{Hg}$ (II) triflate salts had also been successfully employed for the arylallene $\mathbf{1 8 1}$ cyclization by Yamamoto et al [116]. The cata- lytic pathway was proved to involve the direct $\mathrm{H}$-transfer to the vinylmercury complex from the aromatic ring. It involved $\mathrm{Hg}(\mathrm{OTf})_{2}$-catalyzed cyclization of aryl 1,1-disubstituted allenes with the formation of a quaternary carbon center followed by the formation of a cationic vinylmercury intermediate (Scheme 55).

For the synthesis of stereoselective tetrahydropyran derivatives 184, $\mathrm{Hg}(\mathrm{II})$-catalyzed cyclization proved to be more effective than silver(I)-salt-mediated cyclization. It showed that methylsubstituted allenes undergo efficient cyclization to form polycyclic ethers under $\mathrm{Hg}(\mathrm{OTf})_{2}$-catalyzed conditions at lower temperature (Scheme 56) [117].

Following a similar strategy, mercury chlorate $\left(\mathrm{Hg}\left(\mathrm{ClO}_{4}\right)_{2}\right)$ had been employed successfully as a cheap alternative to precious metals salts in the cyclization of $\alpha$-allenol derivatives $\mathbf{1 8 5}$ to differently substituted 2,5-dihydrofurans $\mathbf{1 8 6}$ in an efficient and selective manner. It was also shown that from enantiopure allenyl derivatives, the desired pure cyclized product was generated by utilizing the above reaction conditions (Scheme 57) [118].

\section{Mercury(II)-salt-mediated cyclization in total synthesis}

Apart from previously described cyclization reactions, there were examples where a $\mathrm{Hg}(\mathrm{II})$-salt-mediated cyclization had<smiles>[R]C(=C)CCc1cc[R1]cc1</smiles>

181

182<smiles>C=CC1(C)COCc2cc(OC)ccc21</smiles><smiles>C=CC1(CCCC)COCc2cc(OC)cc(OC)c21</smiles>

$\mathrm{MeO}$<smiles>C=CC1(C)CC(C(=O)OC)(C(=O)OC)Cc2cccc(OC)c21</smiles>

$182 a, 84 \%$

$182 b, 78 \%$<smiles>[R2]C(COCc1cc[R1]cc1)C([R])COCc1ccc[R1](CC)c1</smiles>

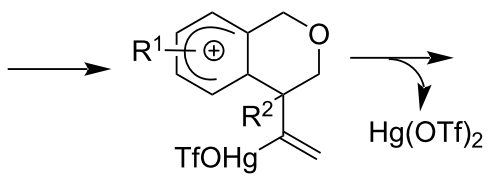




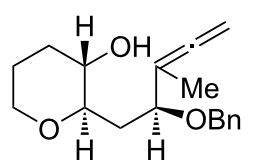

183

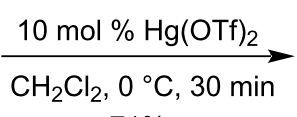

$71 \%$<smiles>C=CC1(O)O[C@@H]2CCCO[C@@H]2C[C@H]1Cc1ccccc1</smiles>

$184 a$<smiles>C=CC1(OCc2ccccc2)[C@H]2C[C@H]3OCCC[C@H]3O[C@](C)(C2)[C@H]1C</smiles>

$184 a$

Scheme 56: Stereoselective synthesis of tetrahydropyran derivatives.

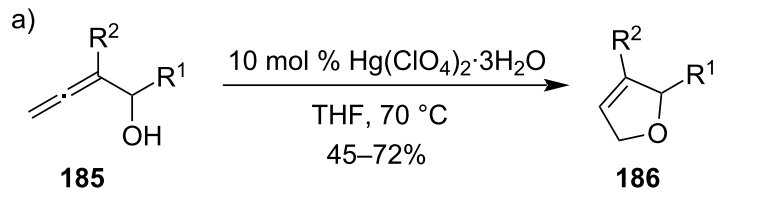

$186 a, 70 \%$<smiles>CC1=CCOC1c1ccc(Cl)cc1</smiles><smiles>CC1=CCOC1Cc1ccccc1</smiles>

186b, $45 \%$<smiles>COc1cc(OC)cc(C2OCC=C2C)c1</smiles>

$186 \mathrm{c}, 57 \%$ b)<smiles>[R]C(C(C)=CC)=C([R])C([R])O</smiles>

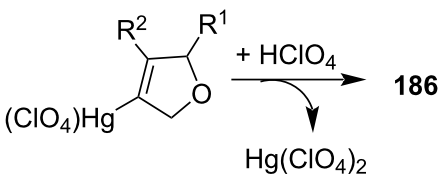

Scheme 57: a) $\mathrm{Hg}\left(\mathrm{ClO}_{4}\right)_{2}$-catalyzed cyclization of $\alpha$-allenol derivatives. b) Simplified mechanism. been successfully employed as one of the important steps during the total synthesis of natural products.

In 1998, a highly enantioselective total synthesis of (+)-furanomycin (190) was achieved through $\mathrm{Hg}(\mathrm{TFA})_{2}$-promoted cyclization of $\gamma$-hydroxyalkene derivative $\mathbf{1 8 7}$ as an intermediate stage to give a mixture of diastereomeric 2,5-disubstituted tetrahydrofurans 188a and 188b (Scheme 58) [119].

Later for the total synthesis of ventiloquinone J (194), a $\mathrm{Hg}(\mathrm{II})$ salt-catalyzed intramolecular cyclization reaction of the orthoallyl alcohol 192 was involved. The reaction went through the formation of a mixture of diastereoisomers 193a and 193b. After which the inseparable mixture of products underwent further oxidative demethylation and yielded the final products (Scheme 59) [120].

Kraus and co-workers had reported the synthesis of the racemic naphthohydroquinone hongconin (197) starting from the orthoallyl alcohol derivative $\mathbf{1 9 5}$. The starting material was cyclized using a $\mathrm{Hg}(\mathrm{II})$ salts to get an inseparable mixture of products 196a and $\mathbf{1 9 6 b}$ in the ratio of $1: 5$ [121]. The synthetic route proceeded by benzylic alcohol ortho-metalation followed by a regioselective mercuri-cyclization reaction (Scheme 60).
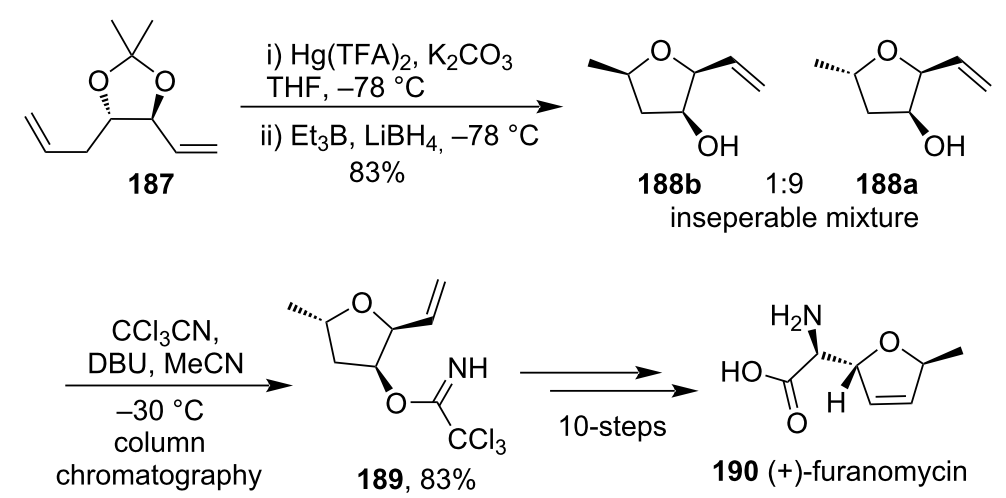
<smiles>C=CCc1c(C(C)=O)c(OC)c2c(OC)cc(OC)c(OC)c2c1CCCCC</smiles>

191

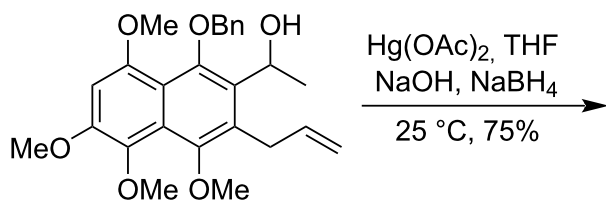

192

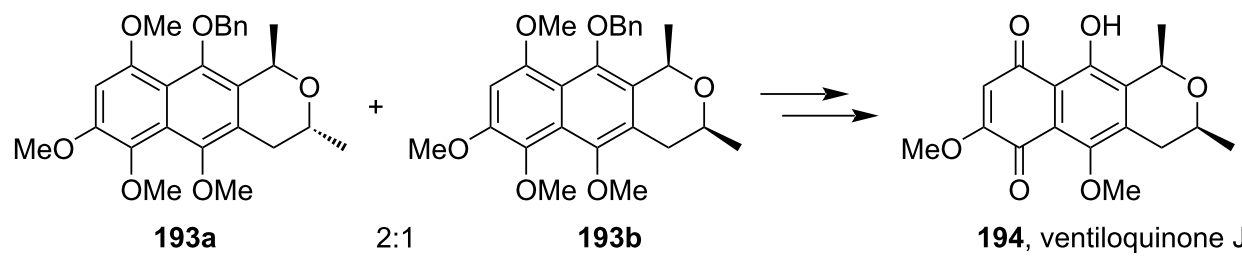

Scheme 59: Synthesis $\mathrm{Hg}$ (II)-salt-mediated cyclization of allyl alcohol for the construction of ventiloquinone J.<smiles>COc1ccc(OC)c(C(C)O)c1</smiles>

195

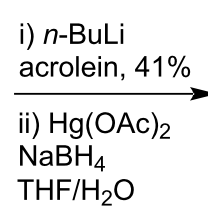

$\mathrm{THF} / \mathrm{H}_{2} \mathrm{O}$<smiles>COc1ccc(OCc2ccccc2)c2c1[C@@H](C)O[C@H](C)[C@H]2O</smiles>

196a, $10 \% \quad 1: 5$<smiles>COc1ccc(OCc2ccccc2)c2c1[C@@H](C)O[C@H](C)[C@H]2O</smiles>

196b, $49 \%$<smiles>COc1cccc2c(O)c3c(c(O)c12)[C@@H](C)O[C@@H](C)C3=O</smiles>

197 , hongconin

Scheme 60: $\mathrm{Hg}(\mathrm{OAc})_{2}$-mediated cyclization as a key step for the synthesis of hongconin.

During the total syntheses of ( \pm )-fastigilin $\mathrm{C}$ and (-)-fastigilin $\mathrm{C}$ (201), 2 equiv of $\mathrm{Hg}(\mathrm{TFA})_{2}$ were used to synthesize key intermediate tricyclic furan compounds 199, 200, and $\mathbf{2 0 3}$. $\mathrm{Hg}$ (TFA $)_{2}$ helped in the desired ring-formation reaction of compound $\mathbf{1 9 8}$ to afford two cyclic compounds $\mathbf{1 9 9}$ and $\mathbf{2 0 0}$ in the ratio of $6: 1$ with an overall $81 \%$ yield [122]. But in the case of methoxy-substituted derivative $\mathbf{2 0 2}$ only one furan derivative $\mathbf{2 0 3}$ was formed (Scheme 61).

In 2007, Nishizawa et al. successfully utilized a $\mathrm{Hg}(\mathrm{OTf})_{2}$-induced cyclization in the key step for the synthesis of $( \pm)$-thallusin (207, Scheme 62). A complex mixture of $\mathrm{Hg}(\mathrm{OTf})_{2}$ and

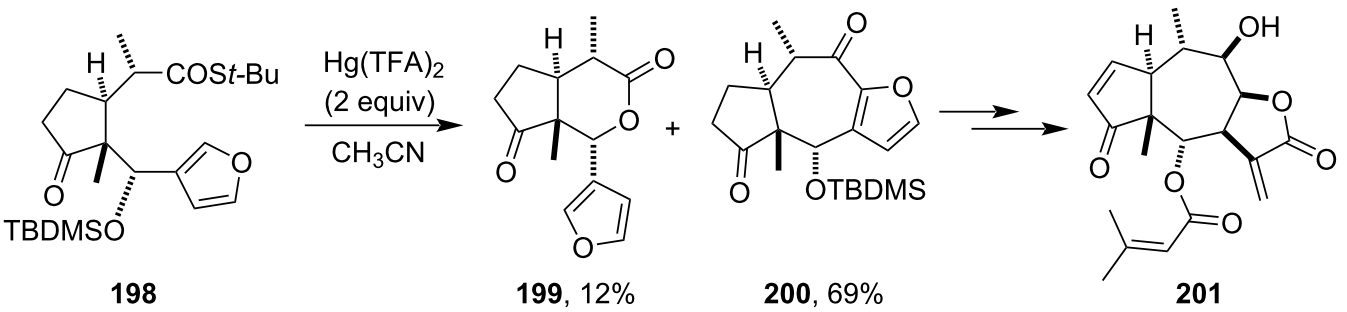

( \pm -fastigilin C

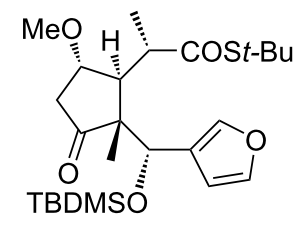

(+)-202

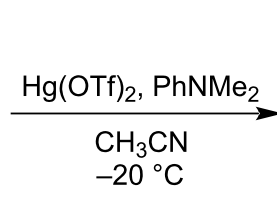<smiles>COC1CC(=O)[C@]2(C)[C@@H](C)C(=O)c3occc3[C@H](OC)[C@@H]12</smiles>

$(+)-203,78 \%$

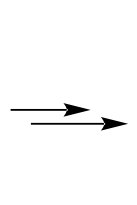<smiles>C=C1C(=O)OC2C(O)[C@H](C)[C@H]3C=CC(=O)[C@]3(C)[C@H](OC(=O)C=C(C)C)C12</smiles>

(-)-fastigilin C 


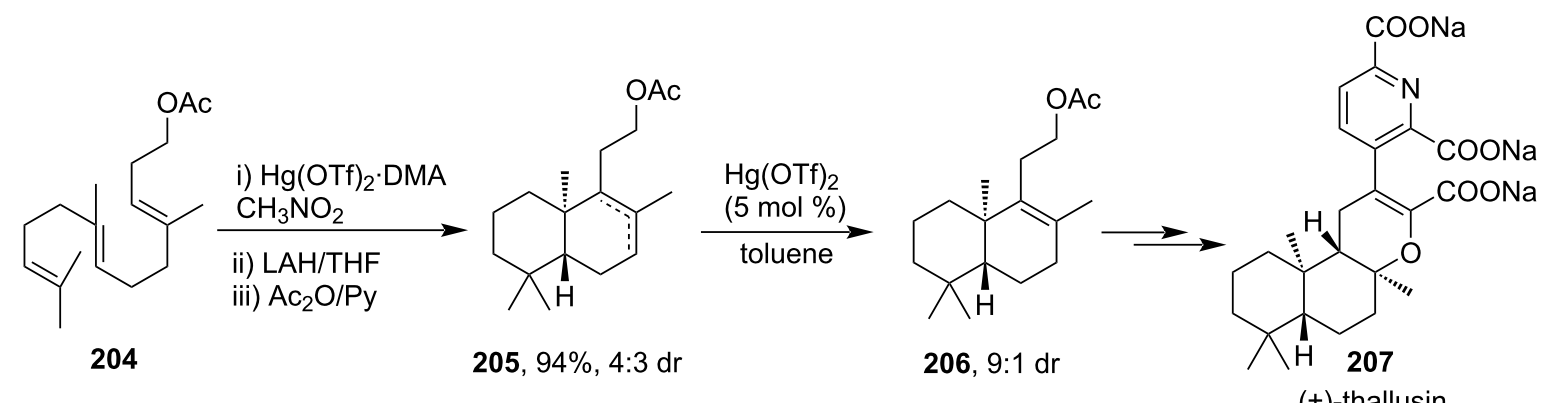

Scheme 62: Formal synthesis of ( \pm )-thallusin.

$N, N$-dimethylaniline (DMA) (1.2 equiv) was initially used for olefin cyclization to produce a regio- and a stereoisomeric mixture of acetate $\mathbf{2 0 5}$ after reduction and acetylation of the crude product. The $\mathrm{Hg}(\mathrm{OTf})_{2}$-catalyzed isomerization of the double bond in compound $\mathbf{2 0 5}$ yielded thermodynamically favorable isomer $\mathbf{2 0 6}$ as a major product [123].

In 2010, Ravindar et al. developed the total synthesis of the steroidal natural product hippuristanol (211) starting from 11-ketotigogenin 208 (Scheme 63). They had utilized a $\mathrm{Hg}(\mathrm{OTf})_{2}$-catalyzed spiroketalization reaction in their key step to form the desired ketal intermediate 210 [124]. Subsequently, in 2011, the same group reported another synthesis of hippuristanol (211) and its analog from easily available starting materials [125]. In this work, hippuristanol and some analogs were successfully synthesized utilizing a $\mathrm{Hg}(\mathrm{OTf})_{2}$-catalyzed cascade spiroketalization step of the 3-alkyne-1,7-diol motif. The $\mathrm{Hg}(\mathrm{OTf})_{2}$-catalyzed cascade spiroketalization step was proved to be more convenient than Suárez cyclization.
A $\mathrm{Hg}$ (TFA) $)_{2}$-mediated cyclization was efficiently utilized for the synthesis of highly strained tricyclo[5.2.1.0 $\left.0^{1,6}\right]$ decene intermediate 214 containing a cyclobutane ring (Scheme 64). Compound $\mathbf{2 1 3}$ is an important precursor for the asymmetric total synthesis of solanoeclepin A. The formation of $\beta$-hydroxyketone 213 was achieved by $\mathrm{Hg}(\mathrm{TFA})_{2}$-mediated cyclization of compound 212 using TFA/ $\mathrm{H}_{2} \mathrm{O}(1.7: 1)$ as the solvent. In presence of other mercury compounds like $\mathrm{HgO}$ and $\mathrm{Hg}(\mathrm{OAc})_{2}$ no product or starting material was recovered [126].

Spiro-skeleton structures are found in many natural products and synthesizing stereoselective spiro-skeletons has always been difficult for organic chemists. Morimoto and co-workers were the first to disclose the $\mathrm{Hg}(\mathrm{OTf})_{2}$-catalyzed cycloisomerization of amino ynone to produce the azaspiro skeleton. Later, this methodology was successfully used for the synthesis of several spiroskeleton structures. Natural products such as histrionicotoxin alkaloids 218 (Scheme 65) [127,128] and lepadoformine $[129,130]$ were being successfully synthesized using

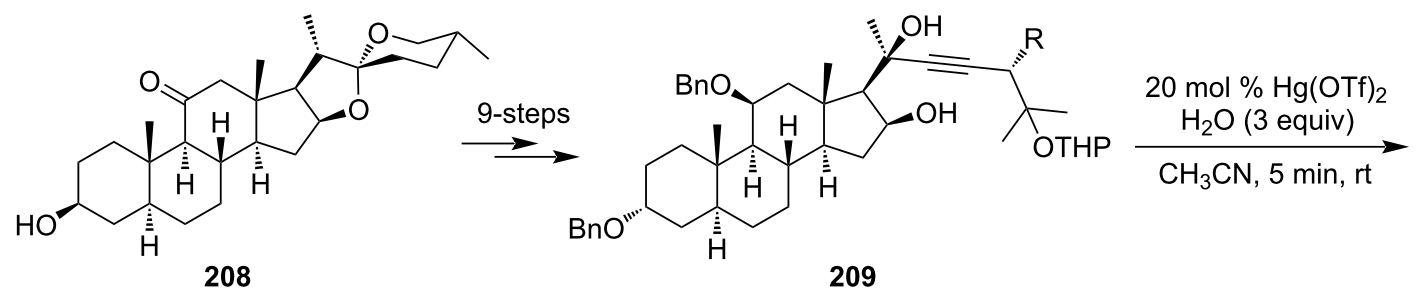

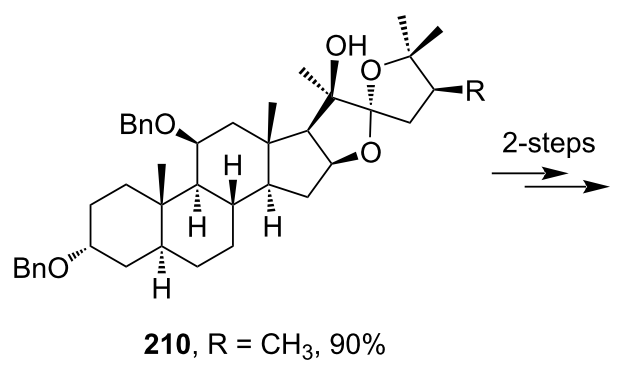

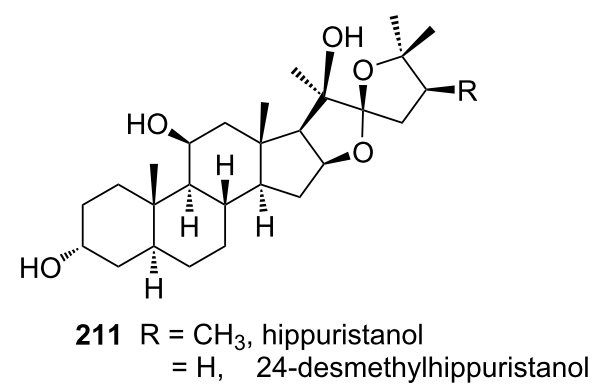




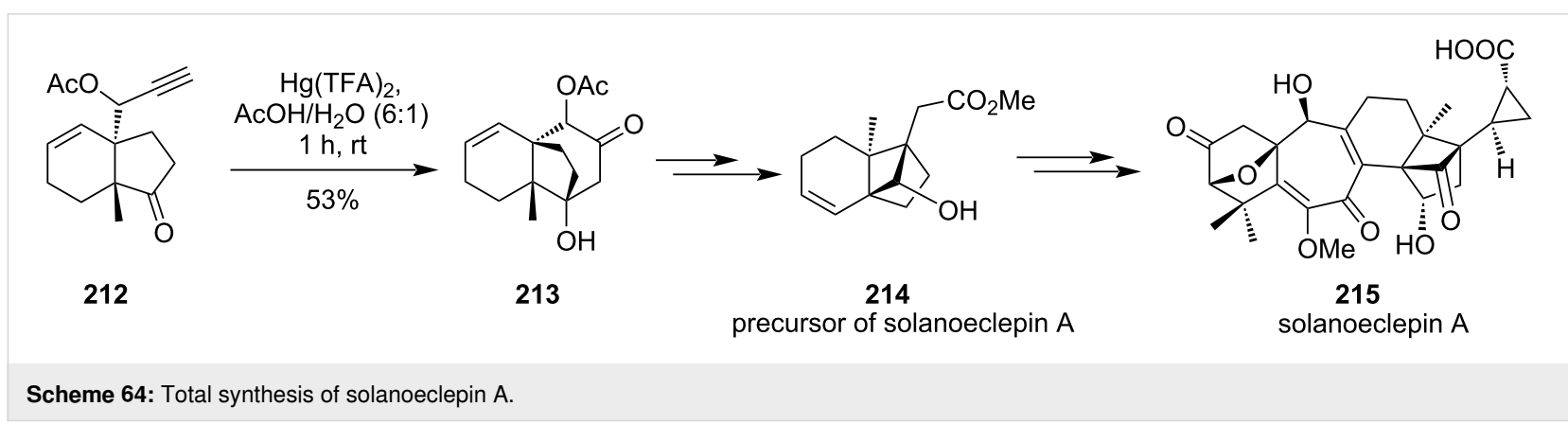

a) $\mathrm{NHBoc}$
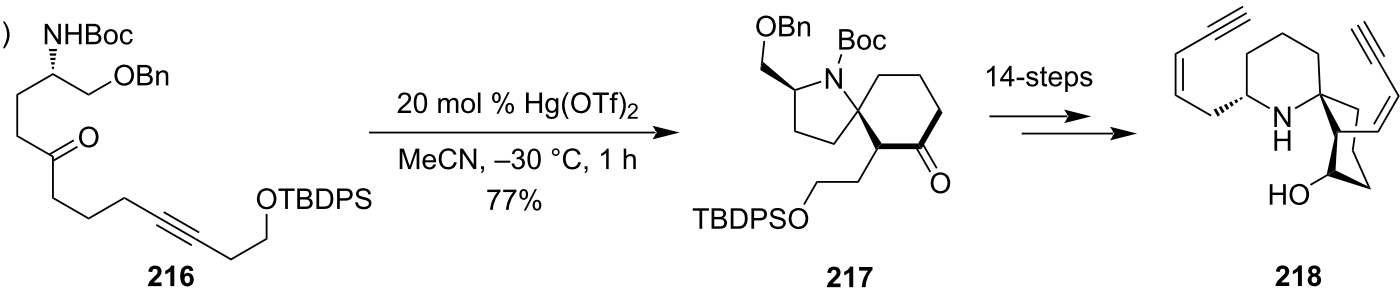

(-)-histrionicotoxin 283A

b) $\mathrm{BnO}$
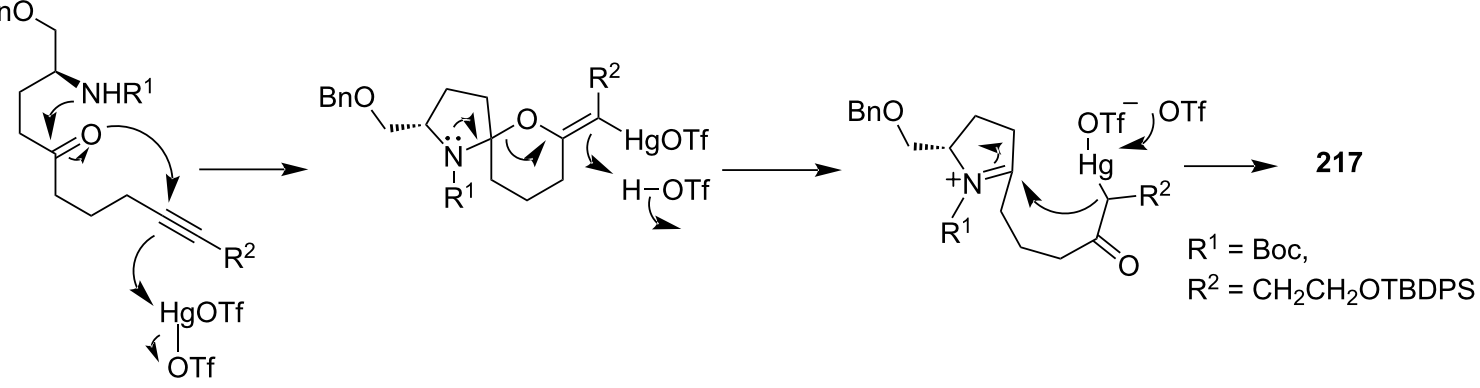

Scheme 65: a) Synthesis of $\mathrm{Hg}(\mathrm{OTf})_{2}$-catalyzed azaspiro structure for the formation of natural products. b) Proposed mechanism for azaspiro formation.

this methodology for spirocyclic ring structure synthesis. The proposed mechanism proceeded initially with aminoketal formation by 6-exo-dig intramolecular oxymercuration, followed by Petasis-Ferrier-type cyclization, and finally nucleophilic addition of mercuric enolate to iminium results in the formation of azaspiro structure.

\section{Conclusion}

In conclusion, this review summarizes $\mathrm{Hg}(\mathrm{II})$-salt-mediated cyclization reactions either for direct synthesis of cyclized products or as a part of the total synthesis of important natural products. Different $\mathrm{Hg}$ (II) salts were used stoichiometrically or catalytically depending upon the nature of functional groups and reactants. However, the reactivity of different unsaturated bonds involved in the cyclization primarily depends on the nucleophile as well as nature of functional groups attached to unsaturated bonds. When alkenes are linked to activating groups like methoxy or hydroxy, a catalytic quantity of $\mathrm{Hg}$ (II) ions is re- quired for cyclization. Nothing can be predicted in case of alkynes; however, the presence of a strong nucleophile promotes the $\mathrm{Hg}$ (II)-salt-catalyzed cyclization of allenes in most circumstances. In cyclization reactions, $\mathrm{Hg}(\mathrm{OTf})_{2}$ showed to be the most effective and versatile of all $\mathrm{Hg}$ (II) salts. Mercury(II) salts can also be used to cyclize unsaturated bonds in a regio- and diastereoselective manner. Apart from toxicity concerns, $\mathrm{Hg}(\mathrm{II})$ salts are cheap, stable, and versatile in terms of reactivity, making them a viable option to similar transition metal catalysts.

\section{Acknowledgements}

The authors would like to express their gratitude to anonymous reviewers for their valuable comments about the manuscript.

\section{Funding}

This work was supported by Department of Chemistry, Cooch Behar Panchanan Barma University. 


\section{ORCID ${ }^{\circledR}$ iDs}

Sumana Mandal - https://orcid.org/0000-0001-9385-3288

Goutam Biswas - https://orcid.org/0000-0002-1488-2003

\section{References}

1. Lautens, M.; Klute, W.; Tam, W. Chem. Rev. 1996, 96, 49-92. doi:10.1021/cr950016l

2. Zhou, F.; Li, C.-J. Chem. Sci. 2019, 10, 34-46. doi:10.1039/c8sc04271c

3. Lou, J.; Wang, Q.; Wu, P.; Wang, H.; Zhou, Y.-G.; Yu, Z. Chem. Soc. Rev. 2020, 49, 4307-4359. doi:10.1039/c9cs00837c

4. Beller, M.; Bolm, C., Eds. Transition Metals for Organic Synthesis: Building Blocks and Fine Chemicals, 1st ed.; Wiley-VCH: Weinheim, Germany, 2004. doi:10.1002/9783527619405

5. Sharma, R.; Kour, P.; Kumar, A. J. Chem. Sci. 2018, 130, 73. doi:10.1007/s12039-018-1466-8

6. Tanaka, K., Ed. Transition-Metal-Mediated Aromatic Ring Construction; John Wiley \& Sons: Hoboken, NJ, USA, 2013. doi:10.1002/9781118629871

7. Solé, D.; Fernández, I., Eds. Advances in Transition-Metal Mediated Heterocyclic Synthesis; Academic Press: London, UK, 2018.

8. Biffis, A.; Centomo, P.; Del Zotto, A.; Zecca, M. Chem. Rev. 2018, 118, 2249-2295. doi:10.1021/acs.chemrev.7b00443

9. Saranya, S.; Rohit, K. R.; Radhika, S.; Anilkumar, G. Org. Biomol. Chem. 2019, 17, 8048-8061. doi:10.1039/c9ob01538h

10. Ruiz-Castillo, P.; Buchwald, S. L. Chem. Rev. 2016, 116, 12564-12649. doi:10.1021/acs.chemrev.6b00512

11. Duarah, G.; Kaishap, P. P.; Begum, T.; Gogoi, S. Adv. Synth. Catal. 2019, 361, 654-672. doi:10.1002/adsc.201800755

12. Seretis, A.; Diamantopoulou, P.; Thanou, I.; Tzevelekidis, P.; Fakas, C.; Lilas, P.; Papadogianakis, G. Front. Chem. (Lausanne, Switz.) 2020, 8, 221. doi:10.3389/fchem.2020.00221

13. Johansson, J. R.; Beke-Somfai, T.; Said Stålsmeden, A.; Kann, N. Chem. Rev. 2016, 116, 14726-14768. doi:10.1021/acs.chemrev.6b00466

14. Fan, X.; Liu, C.-H.; Yu, Z.-X. Rhodium(I)-Catalyzed Cycloadditions Involving Vinylcyclopropanes and Their Derivatives. In Rhodium Catalysis in Organic Synthesis; Tanaka, K., Ed.; Wiley-VCH: Weinheim, Germany, 2019; pp 229-276. doi:10.1002/9783527811908.ch10

15. Wee, A. G. H. Curr. Org. Synth. 2006, 3, 499-555. doi:10.2174/157017906778699512

16. Evans, P. A., Ed. Modern Rhodium-Catalyzed Organic Reactions, 1st ed.; Wiley-VCH: Weinheim, Germany, 2005. doi:10.1002/3527604693

17. Mondal, M.; Bora, U. RSC Adv. 2013, 3, 18716. doi:10.1039/c3ra42480d

18. Carney, J. R.; Dillon, B. R.; Thomas, S. P. Eur. J. Org. Chem. 2016, 3912-3929. doi:10.1002/ejoc.201600018

19. Concellón, J. M.; Rodríguez-Solla, H.; del Amo, V. Chem. - Eur. J. 2008, 14, 10184-10191. doi:10.1002/chem.200800796

20. Hashmi, A. S. K. Chem. Rev. 2007, 107, 3180-3211. doi:10.1021/cr000436x

21. Campeau, D.; León Rayo, D. F.; Mansour, A.; Muratov, K.; Gagosz, F. Chem. Rev. 2021, 121, 8756-8867. doi:10.1021/acs.chemrev.0c00788

22. Boorman, T. C.; Larrosa, I. Chem. Soc. Rev. 2011, 40, 1910-1925. doi:10.1039/c0cs00098a
23. Abbiati, G.; Rossi, E. Beilstein J. Org. Chem. 2014, 10, 481-513. doi:10.3762/bjoc.10.46

24. Wu, Y.-C.; Xiao, Y.-T.; Yang, Y.-Z.; Song, R.-J.; Li, J.-H. ChemCatChem 2020, 12, 5312-5329. doi:10.1002/cctc.202000900

25. Sekine, K.; Yamada, T. Chem. Soc. Rev. 2016, 45, 4524-4532. doi:10.1039/c5cs00895f

26. Larock, R. C. Mercury. Comprehensive Organometallic Chemistry II; Elsevier: Amsterdam, Netherlands, 1995; pp 389-435. doi:10.1016/b978-008046519-7.00100-3

27. Vogt, R. R.; Nieuwland, J. A. J. Am. Chem. Soc. 1921, 43, 2071-2081. doi:10.1021/ja01442a010

28. Ramalingan, C.; Park, Y.-T. J. Org. Chem. 2007, 72, 4536-4538. doi:10.1021/jo070297k

29. Gong, Y.; Cao, Z.-Y.; Shi, Y.-B.; Zhou, F.; Zhou, Y.; Zhou, J. Org. Chem. Front. 2019, 6, 3989-3995. doi:10.1039/c9qo01049a

30. Masuhara, T. Nihon Shika Ishikai Zasshi 1975, 28, 128.

31. Clarkson, T. W.; Magos, L. Crit. Rev. Toxicol. 2006, 36, 609-662. doi:10.1080/10408440600845619

32. Leyva-Pérez, A.; Corma, A. Angew. Chem., Int. Ed. 2012, 51, 614-635. doi:10.1002/anie.201101726

33. Larock, R. C. Angew. Chem., Int. Ed. Engl. 1978, 17, $27-37$. doi:10.1002/anie.197800271

34. Lattes, A. Chem. Heterocycl. Compd. 1975, 11, 4-17. doi:10.1007/bf00945261

35. Kaur, N. Synth. Commun. 2018, 48, 2715-2749. doi:10.1080/00397911.2018.1497657

36. Sand, J. Ber. Dtsch. Chem. Ges. 1901, 34, 1385-1394. doi:10.1002/cber.19010340207

37. Biilmann, E. Ber. Dtsch. Chem. Ges. 1900, 33, 1641-1655. doi:10.1002/cber.19000330235

38. Summerbell, R. K.; Stephens, J. R. J. Am. Chem. Soc. 1954, 76, 6401-6407. doi:10.1021/ja01653a046

39. Summerbell, R. K.; Stephens, J. R. J. Am. Chem. Soc. 1954, 76, 731-734. doi:10.1021/ja01632a028

40. Summerbell, R. K.; Lestina, G.; Waite, H. J. Am. Chem. Soc. 1957, 79, 234-237. doi:10.1021/ja01558a061

41. Pougny, J.-R.; Nassr, M. A. M.; Sinaÿ, P. J. Chem. Soc., Chem. Commun. 1981, 375-376. doi:10.1039/c39810000375

42. Boschetti, A.; Nicotra, F.; Panza, L.; Russo, G. J. Org. Chem. 1988, 53, 4181-4185. doi:10.1021/jo00253a005

43. Nolen, E. G.; Kurish, A. J.; Potter, J. M.; Donahue, L. A.; Orlando, M. D. Org. Lett. 2005, 7, 3383-3386. doi:10.1021/ol051341q

44. Nicotra, F.; Panza, L.; Ronchetti, F.; Toma, L. Tetrahedron Lett. 1984, 25, 5937-5938. doi:10.1016/s0040-4039(01)81725-1

45. Reitz, A. B.; Nortey, S. O.; Maryanoff, B. E. Tetrahedron Lett. 1985, 26, 3915-3918. doi:10.1016/s0040-4039(00)98686-6

46. Andrey, O.; Glanzmann, C.; Landais, Y.; Parra-Rapado, L. Tetrahedron 1997, 53, 2835-2854. doi:10.1016/s0040-4020(97)00003-3

47. Pulido, F. J.; Barbero, A.; Val, P.; Diez, A.; González-Ortega, A. Eur. J. Org. Chem. 2012, 5350-5356. doi:10.1002/ejoc.201200666

48. Mohapatra, D. K.; Mohapatra, S.; Gurjar, M. K. Tetrahedron Lett. 2006, 47, 5943-5947. doi:10.1016/j.tetlet.2006.06.049

49. Enderlin, G.; Nielsen, P. J. Org. Chem. 2008, 73, 6891-6894. doi:10.1021/j0801081t

50. Perie, J. J.; Laval, J. P.; Roussel, J.; Lattes, A. Tetrahedron 1972, 28 , 675-699. doi:10.1016/0040-4020(72)84031-6

51. Roussel, J.; Perie, J. J.; Laval, J. P.; Lattes, A. Tetrahedron 1972, 28, 701-716. doi:10.1016/0040-4020(72)84032-8 
52. Tokuda, M.; Yamada, Y.; Takagi, T.; Suginome, H.; Furusaki, A. Tetrahedron 1987, 43, 281-296. doi:10.1016/s0040-4020(01)89956-7

53. Roubaud, V.; Moigne, F. L.; Mercier, A.; Tordo, P. Phosphorus, Sulfur Silicon Relat. Elem. 1994, 86, 39-54. doi:10.1080/10426509408018386

54. Le Moigne, F.; Mercier, A.; Tordo, P. Tetrahedron Lett. 1991, 32, 3841-3844. doi:10.1016/s0040-4039(00)79391-9

55. Stipa, P.; Finet, J. P.; Le Moigne, F.; Tordo, P. J. Org. Chem. 1993, 58, 4465-4468. doi:10.1021/jo00068a049

56. Dembkowski, L.; Finet, J. P.; Fréjaville, C.; Le Moigne, F.; Maurin, R.; Mercier, A.; Pages, P.; Stipa, P.; Tordo, P. Free Radical Res. Commun. 1993, 19 (Suppl. 1), s23-s32. doi:10.3109/10715769309056s23

57. Le Moigne, F.; Tordo, P. J. Org. Chem. 1994, 59, 3365-3367. doi:10.1021/jo00091a024

58. Roubaud, V.; Moigne, F. L.; Mercier, A.; Tordo, P. Synth. Commun. 1996, 26, 1507-1516. doi:10.1080/00397919608003517

59. Barluenga, J.; Pérez-Prieto, J.; Bayón, A. M.; Asensio, G. Tetrahedron 1984, 40, 1199-1204. doi:10.1016/s0040-4020(01)99327-5

60. Barluenga, J.; Perez-Prieto, J.; Asensio, G.; Garcia-Granda, S.; Salvado, M. A. Tetrahedron 1992, 48, 3813-3826. doi:10.1016/s0040-4020(01)92272-0

61. Carroll, F. I.; Hu, X.; Navarro, H. A.; Deschamps, J.; Abdrakhmanova, G. R.; Damaj, M. I.; Martin, B. R. J. Med. Chem. 2006, 49, 3244-3250. doi:10.1021/jm060122n

62. Peçanha, E. P.; Verli, H.; Rodrigues, C. R.; Barreiro, E. J.; Fraga, C. A. M. Tetrahedron Lett. 2002, 43, 1607-1611. doi:10.1016/s0040-4039(02)00074-6

63. Nixon, J. R.; Cudd, M. A.; Porter, N. A. J. Org. Chem. 1978, 43, 4048-4052. doi:10.1021/jo00415a014

64. Bloodworth, A. J.; Tallant, N. A. J. Chem. Soc., Chem. Commun. 1992, 428-429. doi:10.1039/c39920000428

65. Kurbanov, M.; Semenovsky, A. V.; Smit, W. A.; Shmelev, L. V.; Kucherov, V. F. Tetrahedron Lett. 1972, 13, 2175-2178. doi:10.1016/s0040-4039(01)84798-5

66. Hoye, T. R.; Caruso, A. J.; Kurth, M. J. J. Org. Chem. 1981, 46, 3550-3552. doi:10.1021/jo00330a037

67. Amoroso, R.; Cardillo, G.; Tomasini, C. Tetrahedron Lett. 1990, 31 , 6413-6416. doi:10.1016/s0040-4039(00)97079-5

68. Cardillo, G.; Amoroso, R.; Cardillo, G.; Tomasini, C. Heterocycles 1992, 34, 349. doi:10.3987/com-91-5930

69. Harding, K. E.; Stephens, R.; Hollingsworth, D. R. Tetrahedron Lett. 1984, 25, 4631-4632. doi:10.1016/s0040-4039(01)91218-3

70. Harding, K. E.; Hollingsworth, D. R. Tetrahedron Lett. 1988, 29 , 3789-3792. doi:10.1016/s0040-4039(00)82115-2

71. Takacs, J. M.; Helle, M. A.; Yang, L. Tetrahedron Lett. 1989, 30, 1777-1780. doi:10.1016/s0040-4039(00)99577-7

72. Takacs, J. M.; Helle, M. A.; Takusagawa, F. Tetrahedron Lett. 1989 30, 7321-7324. doi:10.1016/s0040-4039(00)70687-3

73. Majumdar, K. C.; Thyagarajan, B. S. J. Heterocycl. Chem. 1972, 9 , 489-494. doi:10.1002/jhet.5570090305

74. Bates, D. K.; Jones, M. C. J. Org. Chem. 1978, 43, 3856-3861. doi:10.1021/jo00414a015

75. Bates, D. K.; Jones, M. C. J. Org. Chem. 1978, 43, 3775-3776. doi:10.1021/jo00413a032

76. Thyagarajan, B. S.; Majumdar, K. C.; Bates, D. K. J. Heterocycl. Chem. 1975, 12, 59-66. doi:10.1002/jhet.5570120110

77. Balasubramanian, K. K.; Virupaksha Reddy, K.; Nagarajan, R. Tetrahedron Lett. 1973, 14, 5003-5004. doi:10.1016/s0040-4039(01)87633-4
78. Drouin, J.; Boaventura, M. A.; Conia, J. M. J. Am. Chem. Soc. 1985, 107, 1726-1729. doi:10.1021/ja00292a045

79. Riediker, M.; Schwartz, J. J. Am. Chem. Soc. 1982, 104, 5842-5844. doi:10.1021/ja00385a074

80. Compernolle, F.; Mao, H.; Tahri, A.; Kozlecki, T.; Van der Eycken, E.; Medaer, B.; Hoornaert, G. J. Tetrahedron Lett. 2002, 43, 3011-3015. doi:10.1016/s0040-4039(02)00404-5

81. Mao, H.; Koukni, M.; Kozlecki, T.; Compernolle, F.; Hoornaert, G. J. Tetrahedron Lett. 2002, 43, 8697-8700. doi:10.1016/s0040-4039(02)02111-1

82. Atta, A. K.; Kim, S.-B.; Heo, J.; Cho, D.-G. Org. Lett. 2013, 15, 1072-1075. doi:10.1021/ol4000873

83. Larock, R. C.; Liu, C. L. J. Org. Chem. 1983, 48, 2151-2158. doi:10.1021/j000161a007

84. Larock, R. C.; Harrison, L. W. J. Am. Chem. Soc. 1984, 106, 4218-4227. doi:10.1021/ja00327a026

85. Ghorai, S.; Bhattacharjya, A. Org. Lett. 2005, 7, 207-210. doi:10.1021/ol047893a

86. Biswas, G.; Ghorai, S.; Bhattacharjya, A. Org. Lett. 2006, 8, 313-316. doi:10.1021/ol0527274

87. Balasubramanian, T.; Balasubramanian, K. K. Tetrahedron Lett. 1991, 32, 6641-6644. doi:10.1016/0040-4039(91)80243-y

88. Devan, B.; Rajagopalan, K. Synth. Commun. 1994, 24, 1691-1700. doi:10.1080/00397919408010171

89. Tan, D. S.; Schreiber, S. L. Tetrahedron Lett. 2000, 41, 9509-9513. doi:10.1016/s0040-4039(00)01658-0

90. Namba, K.; Nakagawa, Y.; Yamamoto, H.; Imagawa, H.; Nishizawa, M. Synlett 2008, 1719-1723. doi:10.1055/s-2008-1077881

91. Yamamoto, H.; Ho, E.; Namba, K.; Imagawa, H.; Nishizawa, M. Chem. - Eur. J. 2010, 16, 11271-11274. doi:10.1002/chem.201001656

92. Namba, K.; Yamamoto, H.; Sasaki, I.; Mori, K.; Imagawa, H.; Nishizawa, M. Org. Lett. 2008, 10, 1767-1770. doi:10.1021/ol800450x

93. Namba, K.; Kanaki, M.; Suto, H.; Nishizawa, M.; Tanino, K. Org. Lett. 2012, 14, 1222-1225. doi:10.1021/ol2034492

94. Marson, C. M.; Harper, S.; Wrigglesworth, R. J. Chem. Soc., Chem. Commun. 1994, 1879. doi:10.1039/c39940001879

95. Marson, C. M.; Campbell, J. Tetrahedron Lett. 1997, 38, 7785-7788. doi:10.1016/s0040-4039(97)01819-4

96. Marson, C. M.; Harper, S.; Oare, C. A.; Walsgrove, T. J. Org. Chem. 1998, 63, 3798-3799. doi:10.1021/j09715837

97. Krafft, G. A.; Katzenellenbogen, J. A. J. Am. Chem. Soc. 1981, 103, 5459-5466. doi:10.1021/ja00408a030

98. Yamamoto, M. J. Chem. Soc., Chem. Commun. 1978, 649-650. doi:10.1039/c39780000649

99. Yamamoto, M.; Yoshitake, M.; Yamada, K. J. Chem. Soc., Chem. Commun. 1983, 991-992. doi:10.1039/c39830000991

100. Ravindar, K.; Sridhar Reddy, M.; Deslongchamps, P. Org. Lett. 2011, 13, 3178-3181. doi:10.1021/ol201102x

101. McDonald, F. E.; Ishida, K.; Hurtak, J. A. Tetrahedron 2013, 69, 7746-7758. doi:10.1016/j.tet.2013.04.138

102. Hurtak, J.; McDonald, F. Synlett 2017, 28, 2951-2955. doi:10.1055/s-0036-1588562

103. Yamamoto, M.; Tanaka, S.; Naruchi, K.; Yamada, K. Synthesis 1982, 850-852. doi:10.1055/s-1982-29970

104. Nishizawa, M.; Yadav, V. K.; Skwarczynski, M.; Takao, H.; Imagawa, H.; Sugihara, T. Org. Lett. 2003, 5, 1609-1611. doi:10.1021/ol034201u 
105.Sim, S. H.; Lee, S. I.; Seo, J.; Chung, Y. K. J. Org. Chem. 2007, 72, 9818-9821. doi:10.1021/jo701591e

106. Nishizawa, M.; Takao, H.; Yadav, V. K.; Imagawa, H.; Sugihara, T. Org. Lett. 2003, 5, 4563-4565. doi:10.1021/ol035622e

107. Yamamoto, H.; Sasaki, I.; Imagawa, H.; Nishizawa, M. Org. Lett. 2007, 9, 1399-1402. doi:10.1021/ol070335m

108. Imagawa, H.; Kurisaki, T.; Nishizawa, M. Org. Lett. 2004, 6, 3679-3681. doi:10.1021/ol048730p

109. Müller, T. E.; Pleier, A.-K. J. Chem. Soc., Dalton Trans. 1999, 583. doi:10.1039/a808938h

110.Kurisaki, T.; Naniwa, T.; Yamamoto, H.; Imagawa, H.; Nishizawa, M. Tetrahedron Lett. 2007, 48, 1871-1874. doi:10.1016/j.tetlet.2006.12.120

111.Rong, Z.; Hu, W.; Dai, N.; Qian, G. Org. Lett. 2020, 22, 3286-3290. doi:10.1021/acs.orglett.0c01096

112.Zheng, M.; Chen, K.; Zhu, S. Synthesis 2017, 49, 4173-4182. doi:10.1055/s-0036-1588416

113.Zhang, J.; Haider, N. ARKIVOC 2016, No. iii, 125-133. doi:10.3998/ark.5550190.p009.495

114.Lin, C.-H.; Chen, C.-C.; Wu, M.-J. Chem. - Eur. J. 2013, 19, 2578-2581. doi:10.1002/chem.201202704

115.Wen, S.-M.; Lin, C.-H.; Chen, C.-C.; Wu, M.-J. Tetrahedron 2018, 74, 2493-2499. doi:10.1016/j.tet.2018.03.067

116. Yamamoto, H.; Ueda, M.; Yamasaki, N.; Fujii, A.; Sasaki, I.; Igawa, K.; Kasai, Y.; Imagawa, H.; Nishizawa, M. Org. Lett. 2016, 18, 2864-2867. doi:10.1021/acs.orglett.6b01144

117.Suzuki, Y.; Kuwabara, A.; Koizumi, Y.; Mori, Y. Tetrahedron 2013, 69, 9086-9095. doi:10.1016/j.tet.2013.08.026

118. Alcaide, B.; Almendros, P.; Luna, A.; Soriano, E. J. Org. Chem. 2015, 80, 7050-7057. doi:10.1021/acs.joc.5b00887

119. Kang, S. H.; Lee, S. B. Chem. Commun. 1998, 761-762. doi:10.1039/a800727f

120.Giles, R. G. F.; Green, I. R.; van Eeden, N. Synthesis 2004, 1601-1608. doi:10.1055/s-2004-822370

121. Kraus, G. A.; Li, J.; Gordon, M.; Jensen, J. H. J. Org. Chem. 1994, 59, 2219-2222. doi:10.1021/jo00087a044

122. Tanis, S. P.; Robinson, E. D.; McMills, M. C.; Watt, W. J. Am. Chem. Soc. 1992, 114, 8349-8362. doi:10.1021/ja00048a003

123. Nishizawa, M.; lyenaga, T.; Kurisaki, T.; Yamamoto, H.; Sharfuddin, M.; Namba, K.; Imagawa, H.; Shizuri, Y.; Matsuo, Y. Tetrahedron Lett. 2007, 48, 4229-4233. doi:10.1016/j.tetlet.2007.04.075

124.Ravindar, K.; Reddy, M. S.; Lindqvist, L.; Pelletier, J.; Deslongchamps, P. Org. Lett. 2010, 12, 4420-4423. doi:10.1021/ol1019663

125. Ravindar, K.; Reddy, M. S.; Lindqvist, L.; Pelletier, J.; Deslongchamps, P. J. Org. Chem. 2011, 76, 1269-1284. doi:10.1021/jo102054r

126. Chuang, H.-Y.; Isobe, M. Org. Lett. 2014, 16, 4166-4169. doi:10.1021/ol501858w

127. Matsumura, K.; Nishikawa, K.; Yoshida, H.; Doe, M.; Morimoto, Y. RSC Adv. 2018, 8, 11296-11303. doi:10.1039/c8ra02011f

128. Matsumura, K.; Nishikawa, K.; Yoshida, H.; Niwa, T.; Fushii, Y.; Doe, M.; Morimoto, Y. Chem. - Asian J. 2021, 16, 1882-1886. doi:10.1002/asia.202100383

129.Nishikawa, K.; Yamauchi, K.; Kikuchi, S.; Ezaki, S.; Koyama, T.; Nokubo, H.; Matsumura, K.; Kodama, T.; Kumagai, M.; Morimoto, Y. Chem. - Eur. J. 2017, 23, 9535-9545. doi:10.1002/chem.201701475
130.Nishikawa, K.; Kikuchi, S.; Ezaki, S.; Koyama, T.; Nokubo, H.; Kodama, T.; Tachi, Y.; Morimoto, Y. Org. Lett. 2015, 17, 5772-5775. doi:10.1021/acs.orglett.5b02867

\section{License and Terms}

This is an Open Access article under the terms of the Creative Commons Attribution License (https://creativecommons.org/licenses/by/4.0). Please note that the reuse, redistribution and reproduction in particular requires that the author(s) and source are credited and that individual graphics may be subject to special legal provisions.

The license is subject to the Beilstein Journal of Organic Chemistry terms and conditions:

(https://www.beilstein-journals.org/bjoc/terms)

The definitive version of this article is the electronic one which can be found at: https://doi.org/10.3762/bjoc. 17.153 